Yeshiva University, Cardozo School of Law

LARC @ Cardozo Law

Articles

Faculty

2020

\title{
Congressional Administration of Foreign Affairs
}

Rebecca Ingber

Benjamin N. Cardozo School of Law, rebecca.ingber@yu.edu

Follow this and additional works at: https://larc.cardozo.yu.edu/faculty-articles

Part of the Law Commons

\section{Recommended Citation}

Rebecca Ingber, Congressional Administration of Foreign Affairs, 106 Virginia Law Review 395 (2020).

Available at: https://larc.cardozo.yu.edu/faculty-articles/481

This Article is brought to you for free and open access by the Faculty at LARC @ Cardozo Law. It has been accepted for inclusion in Articles by an authorized administrator of LARC @ Cardozo Law. For more information, please contact larc@yu.edu. 


\title{
CONGRESSIONAL ADMINISTRATION OF FOREIGN AFFAIRS
}

\author{
Rebecca Ingber*
}

Longstanding debates over the allocation of foreign affairs power between Congress and the President have reached a stalemate. Wherever the formal line between Congress and the President's powers is drawn, it is well established that, as a functional matter, even in times of great discord between the two branches, the President wields immense power when he acts in the name of foreign policy or national security.

And yet, while scholarship focuses on the accretion of power in the presidency, presidential primacy is not the end of the story. The fact that the President usually "wins" in foreign affairs does not mean that the position the President ultimately chooses to take is preordained. Questions of foreign policy and national security engage diverse components of the executive branch bureaucracy, which have overlapping jurisdictions and often conflicting biases and priorities. And yet they must arrive at one executive branch position. Thus the process of decision making, the weight accorded the position of any given decision maker, and the context in which the decision is made together shape the ultimate position the President takes.

This Article explores and critiques the foreign policy role Congress can-and does-play in structuring and rearranging the relative powers of those internal actors and the processes they take to reach

* Associate Professor of Law, Boston University School of Law, and Senior Fellow, Reiss Center on Law and Security at NYU School of Law. I am indebted to Julian Arato, Jack Beermann, Pam Bookman, Curt Bradley, Jessica Bulman-Pozen, Josh Chafetz, Kathleen Claussen, Ashley Deeks, Kristen Eichensehr, Ryan Goodman, Rebecca Hamilton, Kathryn Kovacs, Harold Krent, Gary Lawson, David Lewis, Henry Monaghan, David Noll, Anne Joseph O'Connell, Nicholas Parrillo, David Pozen, Michael Ramsey, Robert Sloane, Peter Spiro, Kevin Stack, and Matthew Waxman, as well as participants at the Duke-Yale Foreign Relations Law Roundtable, the Vanderbilt International Law Roundtable, the NYU Hauser Colloquium, the Berkeley Law Public Law \& Policy Workshop, the Junior International Law Scholars Association Workshop, the AALS New Voices in Administrative Law workshop, the Fourth Annual Administrative Law New Scholarship Roundtable, and faculty workshops at Brooklyn, BU, Cardozo, Hastings, Fordham, and Rutgers Law, for generous discussions and feedback on drafts at many stages of this project. For excellent research assistance, I thank Chloe Aubuchon, James Black, Caroline Lambert, and Tyler Shearer. 
their decisions, in order to influence and even direct the President's ultimate position. Having yielded much of the ground on substance, Congress has an opportunity for a second bite at the apple, and may influence the policy directions of the presidency by manipulating its internal workings. There are risks to deploying "process controls," as I term these measures, in lieu of direct substantive engagement, but I argue that Congress can and should use these tools more instrumentally to influence the course of foreign policy in areas where it is otherwise unlikely to assert itself as a coequal branch and necessary check on presidential power.

INTRODUCTION 397

I. ForEIGN AFFAIRS POWER AND BUREAUCRATIC CONTROLS 405

A. Congressional-Executive Allocations of Foreign

Affairs Power 405

B. Congressional Control of the Bureaucracy............................ 408

II. Process CONTROLS AS TOOLS OF Foreign POLICY ....................... 412

A. Foreign Policy Through Institutional Design......................... 415

B. Foreign Policy Through Administrative Procedure.................. 419

C. Foreign Policy Through Designated Deciders........................ 421

1. Vertical Shift in Decider .............................................. 422

2. Horizontal Shift in Decider ............................................ 425

3. Excision of Decision-Making Responsibility and Power.

4. Diffusion of Decision-Making Responsibility and Power....

5. Implicit Allocations of Decision-Making Power ................ 436

III. IMPLICATIONS OF CONGRESSIONAL ADMINISTRATION .....................437

A. Why Deploy Process Controls to Influence Foreign Policy ..... 438

1. Why Do Process Controls Surmount Congressional Reticence?

2. Process Controls and Purpose ........................................ 441

B. Efficacy of Congressional Administration.............................. 443

1. The State of Play Inside the Executive Branch.................. 444

2. Process Controls: Formal or Functional Barriers?........... 447

3. Harnessing of Accountability Mechanisms...................... 450

C. Risks in Congressional Administration .................................. 451

1. Constitutional Risks in Congressional Administration....... 452

2. Mollification of Congress............................................... 456

3. Overeager and Unwilling Deciders................................ 458 
4. Surreptitious Interference with Political Will

5. Risks to Accountability and Transparency.

CONCLUSION.

\section{INTRODUCTION}

Longstanding debates over the allocation of foreign affairs power between Congress and the President have reached a stalemate. Wherever the line between Congress and the President's formal authority is drawn, it is well established that, as a functional matter, even in times of great discord between the two branches, the President wields immense power when he acts in the name of foreign policy or national security.

But presidential primacy is not the end of the story. While the President might wield far-reaching control over the nation's foreign affairs and national security policies, Congress can shape the President's position, and thus the foreign policy of the United States, without necessarily mandating the substance of that policy itself.

This Article explores and critiques the foreign policy role Congress can - and does - play through structuring and rearranging the relative powers of internal executive branch actors and the processes they take to reach their decisions, in order to influence and even direct the President's ultimate position. Having yielded much of the ground on substance, Congress has an opportunity for a second bite at the apple, and may influence the policy directions of the presidency simply by manipulating its internal workings.

A recent example illustrates the point. In 2017, the newly elected President threatened a trade war with China, Mexico, Canada and other longtime allies and competitors around the globe, proposing high tariffs on imports of steel and specific products, such as foreign-made vehicles. ${ }^{1}$ His own political party controlled the House and Senate, but there was little appetite in Congress for raising tariffs. So he turned inward, looking

1 The President's 2017 Trade Policy Agenda, Office of the U.S. Trade Representative (2017), https://ustr.gov/sites/default/files/files/reports/2017/AnnualReport/Chapter\%20I\%20-\%20The \%20President\%27s\%20Trade\%20Policy\%20Agenda.pdf [https://perma.cc/GV4T6289]; Bob Bryan \& Elena Holodny, Trump's Considering a Tariff That Could Put the Economy on a Path to 'Global Recession,' Business Insider (June 30, 2017, 10:24 AM), https://www.businessinsider.com/trump-steel-tariff-china-germany-japan-global-recession2017-6 [https://perma.cc/S2QY-YNL8]; Peter S. Goodman, Trump's Trade War May Have Already Begun, N.Y. Times (Jan. 30, 2017), https://www.nytimes.com/2017/01/30/business/economy/trumps-mexico-china-tariff-trade.html [https://perma.cc/M5WH-PMVR]. 
to his own cabinet to effectuate his plans. Government lawyers dusted off a rarely-used delegation from Congress, Section 232 of the Trade Expansion Act of 1962, which permits the President to adjust restrictions on imports when the Secretary of Commerce finds that they impose a threat to national security. ${ }^{2}$

With his statutory authority contingent upon meeting this procedural requirement, the President demanded that the Commerce Secretary consider the effects on national security of steel and aluminum imports, asserting meanwhile, in an expansive interpretation of this statutory exception, that the nation's economic welfare is itself a matter of national security. ${ }^{3}$ The Secretary of Commerce, following the statute's requirements, consulted with the Secretary of Defense, who told him, in a diplomatically-worded missive, that the adjustments proposed by Commerce were in fact unnecessary for national security, and could have negative consequences for U.S. relationships with important allies. ${ }^{4}$ Those steps taken, and despite the Defense Secretary's warning, the President moved ahead on the Commerce Secretary's report, imposing additional tariffs on both steel and aluminum imports. ${ }^{5}$

Members of the President's own party in Congress issued unusual rebukes of the President's action, denouncing the measures as a "tax hike on American manufacturers, workers and consumers," 6 asking the

219 U.S.C. $\$ 1862$ (b)-(c) (2012). Prior to the Trump Presidency, presidential authority to impose tariffs had only been exercised a total of five times across the authority's sixty-fouryear existence that began with a temporary authorization in 1955. Rachel F. Fefer et al., Cong. Research Serv., R45249, Section 232 Investigations: Overview and Issues for Congress app. b, at 35 (2018).

${ }^{3}$ Memorandum on Aluminum Imports and Threats to National Security, 2017 Daily Comp. Pres. Doc. 284 (Apr. 27, 2017); Memorandum on Steel Imports and Threats to National Security, 2017 Daily Comp. Pres. Doc. 259 (Apr. 20, 2017).

${ }^{4}$ Letter from James N. Mattis, Sec'y of Def., to Wilbur L. Ross Jr., Sec'y of Commerce (2018), https://www.commerce.gov/sites/default/files/department_of_defense_memo_response_to_steel_and_aluminum_policy_recommendations.pdf [https://perma.cc/HA7Y-UWL6] [hereinafter Letter from Mattis to Ross] ("As noted in both Section 232 reports, however, the U.S. military requirements for steel and aluminum each only represent about three percent of U.S. production. Therefore, DoD does not believe that the findings in the reports impact the ability of DoD programs to acquire the steel or aluminum necessary to meet national defense requirements.").

${ }^{5}$ Fefer et al., supra note 2, at 7 . The President also negotiated exceptions on a country-bycountry basis. Id. at 7-9.

${ }^{6}$ Press Release, U.S. Senate Comm. on Fin., Hatch Statement on Steel, Aluminum Tariffs (Mar. 8, 2018), https://www.finance.senate.gov/chairmans-news/hatch-statement-on-steel-aluminum-tariffs [https://perma.cc/42YF-KMX8]. 
President to dial back the global tariffs, ${ }^{7}$ and most recently passing legislation mandating a report from the Secretary of Commerce. ${ }^{8}$ Congress did not, however, exercise its power to withdraw the President's authority to adjust imports, an authority that Congress itself had given to the President through increasingly expansive delegations since the 1930s. ${ }^{9}$

Yet congressional reticence to reassert dominance over trade policy is not the end of the story. There is another tool of control that members of Congress might deploy and which, despite increasingly relinquishing power to the President, Congress has used several times before in order to influence the direction of U.S. trade policy. And that is to restructure the decision-making process inside the executive branch in order to preference decision makers and processes more likely to favor their preferred outcomes.

Indeed, members of Congress have introduced several bills seeking to do just that. In 2018 and 2019, several bipartisan groups of lawmakers introduced bills in both the House and Senate to retract from the Secretary of Commerce the power to invoke a national security justification for raising tariffs on foreign imports. ${ }^{10}$ The bills would grant that power instead to the Secretary of Defense - the very cabinet secretary who had, as the bill proponents surely noticed, criticized the Commerce Secretary's proposed indiscriminate tariffs. ${ }^{11}$ Such micro-management over the

\footnotetext{
${ }^{7}$ Vicki Needham, Ways and Means Sets Hearing on Trump's Tariffs, The Hill (Apr. 5, 2018, 5:17 PM), https://thehill.com/policy/finance/381875-ways-and-means-set-hearing-on-trumps-tariffs [https://perma.cc/AN9E-98LU].

${ }^{8}$ Consolidated Appropriations Act, 2020, Pub. L. No. 116-93, § 112, 133 Stat. 2317, 239596 (2019) (requiring publication of the Secretary of Commerce's findings in automobiles and automotive parts market within thirty days of enactment). The Administration has thus far resisted complying with this provision. See Steven A. Engel, Office of Legal Counsel, Publication of a Report to the President on the Effect of Automobile and Automobile-Part Imports on the National Security 1-2 (Jan. 17, 2020), https://www.justice.gov/olc/opinion/file/1236426/download [https://perma.cc/YYC3-AHW6] (arguing that President may assert executive privilege over Secretary of Commerce's automobile and automobile parts report).

${ }^{9}$ See infra Subsection II.C.1 (detailing historical development of the national security justification for imposing tariffs).

10 Trade Security Act of 2019, S. 365, 116th Cong. (2019); Bicameral Congressional Trade Authority Act of 2019, S. 287, 116th Cong. (2019); H.R. 6923, 115th Cong. § 4 (2018); S. 3329,115 th Cong. $\$ 2$ (2018).

${ }^{11}$ See Letter from Mattis to Ross, supra note 4. Former Defense Secretary Mattis resigned between the 2018 and 2019 bill proposals, but press releases accompanying the 2019 proposals, such as one stating the purpose was to counter "misuse" of the national security justification and "to ensure that the statute is used for genuine national security purposes,"
} 
executive branch decision maker is not an untested tool for Congress. In fact, the bills would make the Office of the Defense Secretary at least the sixth distinct congressionally designated executive branch office to wield that authority since Congress began delegating away its power over the nation's trade policy. ${ }^{12}$

Why might members of Congress who want to challenge the President's trade policies deploy an indirect tool of micro-management over the executive branch's decision-making process, rather than simply direct the policy themselves through substantive legislation? And could such an indirect tool have any real effect?

In fact, indirect tools such as the choice of executive branch decision maker or the restructuring of internal decision-making processes can entirely redirect the President's policy outcomes, and members of Congress often have reason to prefer these mechanisms to more direct legislation. Thus, while Congress may defer or even delegate to the President on matters of substantive foreign policy - and while members of Congress may not rest assured that the President will implement their will even when they do mandate substance - Congress may nevertheless shape the nation's foreign policy through what I term "congressional administration." 13

suggest that bill proponents view the Defense Department's constraining effect on the use of the national security justification as departmental rather than unique to Mattis. See Press Release, Sen. Rob Portman, Portman, Jones, Ernst, Alexander, Feinstein, Fischer, Sinema \& Young Introduce Trade Security Act to Reform National Security Tariff Process (Feb. 6, 2019), https://www.portman.senate.gov/newsroom/press-releases/portman-jones-ernst-alexander-feinstein-fischer-sinema-young-introduce [https://perma.cc/4DQZ-AVE4] [hereinafter Press Release, Sen. Rob Portman].

12 See generally Edward E. Groves, A Brief History of the 1988 National Security Amendments, 20 Law \& Pol'y Int'l Bus. 589, 590-93 (1989) (detailing the ways in which Congress has empowered other agencies to conduct trade policy). The executive agents who have been tasked with fulfilling the requirements of Section 232 include: Director of Defense Mobilization (1955), Director of the Office of Defense and Civilian Mobilization (1958), Director of the Office of Emergency Planning (1962), Director of the Office of Emergency Preparedness (1968), Secretary of the Treasury (1974), and Secretary of Commerce (1979). Id.

${ }^{13}$ I use this term as a congressional corollary to then-Professor Elena Kagan's "Presidential Administration," which she identified as presidential control of the bureaucracy as a means to advance "the President's own policy and political agenda," particularly in the face of political obstacles to doing so through other means. Elena Kagan, Presidential Administration, 114 Harv. L. Rev. 2245, 2248 (2001). Professor Jack Beermann uses this term directly, to describe Congress's ongoing involvement in the "day to day administration of the law." Jack M. Beermann, Congressional Administration, 43 San Diego L. Rev. 61, 64 (2006). 
Congressional administration, as I define it here, is the management and manipulation of internal executive branch decision-making processes for the purpose of advancing a substantive agenda. Congress has an array of measures that it may deploy to influence the nation's foreign policy, short of mandating the substance itself. These "process controls" include familiar tools such as agency design and procedural requirements, but they also include the designation and reassignment of decision makers within the executive branch. Each of these may be deployed for different purposes, with different effects and risks, and each may have significant effects on the ultimate policy direction the United States takes.

This Article sits at the intersection of two broad bodies of literature: one on congressional-executive turf wars over foreign affairs and national security, and one on agency design and political control over the bureaucracy. Scholars have long debated the proper constitutional allocation of power between the President and Congress over the direction of the nation's foreign policy. As a practical matter, however, the conventional wisdom holds that "the President (almost) always wins in foreign affairs." 14 The reasons for presidential primacy are legion: institutional competence; asymmetrical expertise and information; and more costs than benefits to Congress in engaging. Moreover, many argue that even when Congress does engage directly and substantively on a matter, the President often manages to assert authority to act, either by interpreting his statutory authorities broadly, ${ }^{15}$ or by claiming a constitutional prerogative to act unilaterally, ${ }^{16}$ or even by skirting the legal constraints altogether. ${ }^{17}$

But the fact that the President usually "wins" vis-à-vis Congress does not mean that the position the President ultimately chooses to take is

${ }^{14}$ Harold Hongju Koh, Why the President (Almost) Always Wins in Foreign Affairs: Lessons of the Iran-Contra Affair, 97 Yale L.J. 1255, 1291 (1988); see also Aaron Wildavsky, The Two Presidencies, 4 Trans-Action 7 (1966) (arguing that presidents typically receive support or, at least, a lack of pushback from Congress on their foreign policy agenda).

${ }^{15}$ See Libya and War Powers: Hearing Before the S. Comm. on Foreign Relations, 112th Cong. 7-11 (2011) (statement of Harold Koh, Legal Adviser, U.S. Dept. of State); see also Adrian Vermeule, Our Schmittian Administrative Law, 122 Harv. L. Rev. 1095 (2009) (arguing that administrative law is sufficiently vague to enable Presidents to act without constraint at the invocation of an emergency, and that this is inevitable).

${ }^{16}$ See Zivotofsky v. Kerry, 135 S. Ct. 2076, 2086 (2015).

${ }^{17}$ For a bit of all three, see Memorandum from Jay S. Bybee, Assistant Attorney Gen., U.S. Dep't of Justice, to Alberto R. Gonzales, Counsel to the President, Exec. Office of the President (Aug. 1, 2002), https://www.justice.gov/olc/file/886061/download [https://perma.cc/AM56-F4TD]. 
preordained. Nor does it mean that the policy the President ultimately adopts at the end of what is often a long and contentious decision-making process is the one he would have chosen if all possible options were simply laid out before him at the outset. In fact, presidential primacy does not even mean that the policy the President ultimately adopts has actually received the personal sign-off of the President.

Indeed there is another dynamic beyond that of the President-Congress relationship that is essential to understanding foreign policy positioning and is as much of a hotbed for diversity of opinion. This is the multifaceted, many-headed organism that is the executive branch bureaucracy. That there is a diversity of opinion within the executive branch, especially on matters of foreign policy and national security, should be clear these days to anyone who picks up a newspaper. ${ }^{18}$ That the process for decision making inside the executive branch influences the resulting policies is perhaps less intuitive, particularly to those who envision a unitary executive headed by a willful President with his fingers in every pot. And yet it is so. Furthermore, there exist opportunities for influencing these processes, and thus the resulting policy, from the outside. Of specific relevance here, Congress has robust means at its disposal to shape these processes and thus the resulting decision.

I have written previously about the multiplicity of decision makers, processes, overlapping interests, and conflicting proclivities inside the executive branch, and the potential for external actors to shape the President's positions by triggering different decision-making pathways. ${ }^{19}$ I focused in prior work on the role of litigants, nongovernmental organizations, and international treaty bodies in prompting different processes and the potential for achieving different outcomes. ${ }^{20}$ But members of Congress have far greater opportunities than most for triggering and even for restructuring different decision-making pathways, including for designating their preferred internal official as the decider over a given matter.

While executive branch decision making may at times appear opaque from the outside - particularly in the realm of foreign policy and national security-savvy government watchers, scholars, and even members of Congress can often glean a sense of its inner workings: which matters are

\footnotetext{
${ }^{18} \mathrm{Or}$, if this is anachronistic, then to anyone who is on Twitter.

${ }^{19}$ Rebecca Ingber, Interpretation Catalysts and Executive Branch Legal Decisionmaking, 38 Yale J. Int'1 L. 359, 369-73 (2013) [hereinafter Ingber, Interpretation Catalysts].

${ }^{20} \mathrm{Id}$.
} 
subject to internal debate, who within the administration may be inclined toward particular policies, and where the pressure points lie for decision making. ${ }^{21}$ Actors inclined to lean into these pressure points may therefore find they can influence policy outcomes simply by exerting influence on the shape of executive branch decision making.

Members of Congress have especially potent tools for shaping the process of decision making, through legislation directly creating procedural requirements or designating decision makers, as well as through "soft" mechanisms such as requests for testimony from particular executive branch officials, ${ }^{22}$ all of which can shape and shift presidential priorities, force to a head executive branch decisions, exacerbate internal tensions, or place a thumb on the scale in favor of a particular set of actors engaged in intra-executive branch conflict. Through the use of these process controls, Congress can and does shape the process of executive branch decision making and influence policy without necessarily mandating a particular substantive outcome.

This Article proceeds as follows: Part I first considers scholarly debates over the legal and practical allocation of the foreign affairs power, including the extent to which Congress is able effectively to constrain the President in this sphere. Acknowledging the practical reality of presidential primacy in matters of foreign affairs, it turns to scholarship considering the interaction of Congress with the internal workings of the executive branch bureaucracy. This scholarship largely brackets off the fields of foreign policy and national security, thus bringing insights from administrative law and political science scholarship on political control of the bureaucracy to bear on debates about the allocation of foreign policy power is one contribution of this Article.

Part II introduces and classifies what I term "process controls," the mechanisms that Congress may deploy to influence the executive branch decision-making process, and through it, the shape of foreign policy. Two types of measures that I include within the term process controls - agency design and the imposition of administrative procedures - have been the

\footnotetext{
${ }^{21}$ In fact, members of Congress often have significant ties to the executive branch both through their own personal relationship to members of the political class within the administration and through staffers' often deep connections to agencies through prior positions, former colleagues, and the fact that they are repeat players on specific issues. See, e.g., Ashley Deeks, Statutory International Law, 57 Va. J. Int'l L. 263, 296-97 (2018).

${ }^{22}$ See Josh Chafetz, Congress's Constitution: Legislative Authority and the Separation of Powers 3 (2017) (arguing that Congress has many tools, including both "hard" like appropriations and "soft" like speech, which it underutilizes).
} 
subject of significant scholarship in both administrative law and political science..$^{23}$ I therefore consider these each in turn in order to examine their relevance and influence on questions of foreign policy and national security, which are generally excluded from scholarship concerning agency design and administrative procedure.

I devote the majority of this Part, and of the Article, to identifying and analyzing a specific type of process control that has not been the focus of scholarship: the designation of executive branch decision makers. Among the controls I discuss in this Article, Congress wields significant, targeted control over decision making inside the executive branch simply through its choice of the intra-executive decider. This is not a one-off decision; Congress may - and does-reassign the decision maker as new events arise or policy preferences shift. Members of Congress thus may seek to shift a delegation of authority horizontally, from one executive branch official or office to another who may espouse policy preferences more in sync with their own. Or they may allocate power vertically, such as upward toward a high-level official if they are looking to increase political accountability for a decision, or downward to professionals and technocrats when seeking to buffer an issue from partisan politics. Or they may try to diffuse power, perhaps as a means of constraining government action, by requiring consultation among or even certification by several different officials.

Part III considers the implications of Congress turning to process controls to shape foreign policy. It considers when and why Congress might turn to process controls over more direct efforts to mandate substance, and which particular process controls are likely to be effective at implementing particular purposes. This Part also probes the unique constitutional questions raised by congressional administration of foreign policy, as well as the risks at stake-risks to good government and to accountability for decision making.

In considering the influence of internal decision makers and processes on executive branch policy and Congress's ability to influence its direction through these processes, this Article also adds texture to debates about a "unitary executive" model of executive branch decision making. I discuss the implications of process controls for formal doctrine and the potential for judicial review in Part III. But the influence of process controls on policy I discuss in this paper more broadly provides a

${ }^{23}$ See infra Part II. 
functional critique of unitary executive theory. Wherever the line ultimately falls on the formal powers of the President over those within the executive branch, the multiplicity of decision makers and processes will always provide practical opportunities for influencing and even manipulating executive branch policies, from within the executive branch and without.

Congress has ceded significant ground to the President on matters of foreign policy and national security, and continues to do so, often abdicating its responsibility to craft policy or to provide substantive, rigorous oversight. Moreover, Congress has at times lost ground to the President even when it has attempted to assert its prerogative. ${ }^{24}$ But this Article nevertheless challenges views of the presidency as completely untethered to law or to congressional constraint. Congress may be overly timid in this space, and it may at times be ineffective. But it can and does exercise its power to shape foreign policy short of mandating substance, and it could deploy these process controls even more instrumentally to impel decision making in its preferred direction. Though the focus here is on foreign policy and national security decision making, this consideration of process controls has relevance beyond these spheres, to stillnascent questions of how Congress interacts with the levers and pulleys effectuating decisions inside the executive branch.

\section{ForeIgn AfFAIRs Power AND BuREAUCRATIC CONTROLS}

This Article sits at the intersection of two broad bodies of literature: one on congressional-executive power struggles over foreign affairs and national security, and one on agency design and political control over the bureaucracy.

\section{A. Congressional-Executive Allocations of Foreign Affairs Power}

It has long been conventional wisdom that the President exercises significantly more control over foreign affairs than does Congress. As a matter of constitutional authority, scholars continue to debate the proper allocation of foreign affairs power between the President and Congress. ${ }^{25}$

\footnotetext{
${ }^{24}$ See Zivotofsky v. Kerry, 135 S. Ct. 2076, 2086 (2015).

25 Compare Saikrishna B. Prakash \& Michael D. Ramsey, The Executive Power over Foreign Affairs, 111 Yale L.J. 231, 233-34 (2001) (arguing that the President has significant foreign affairs power, including a "residual" foreign affairs power within the executive power), with Julian Davis Mortenson, Article II Vests the Executive Power, Not the Royal
} 
And yet as a practical matter, the question quite rarely comes to a head. ${ }^{26}$ This is not for lack of possible flashpoints, but rather because Congress rarely deploys all the power it clearly holds, let alone tries to push the envelope. In fact, Congress has a wide range of methods at its disposal for exercising direct authority over foreign affairs well within its explicitly allocated authority-from committee oversight to appropriations to declarations of war. ${ }^{27}$ Yet members of Congress have often been reticent to use this power, for reasons both practical and political, and Congress's formal authority generally well exceeds its functional willingness to deploy it. To the extent that longstanding practice affects the balance of powers among the branches, this acquiescence by Congress in the executive's stranglehold on foreign affairs may even result in a formal shift in power to the executive over time. ${ }^{28}$

The reasons for congressional reticence to get involved in foreign policy are overdetermined. ${ }^{29}$ Some are based in rational justifications like institutional competence and good government. Much of the foreign affairs and national security expertise is now housed in the executive branch, and thus some level of deference to their more granular knowledge may be justified. ${ }^{30}$ Exponential increases in complexity and classification lead to significant information asymmetries between the branches. ${ }^{31}$ And to the extent it is advantageous that the state speak with

Prerogative, 119 Colum. L. Rev. 1169, 1172-73 (2019) (arguing that the Vesting Clause is nothing more than the "authority to carry out projects defined by a prior exercise of the legislative power").

26 A recent notable exception is the case of Zivotofsky v. Kerry, in which the State Department refused to implement a statutory requirement that passports for individuals born in Jerusalem list the place of birth as "Israel." 135 S. Ct. at 2083. The Supreme Court heard the case and held that the statutory requirement impermissibly infringed on the President's plenary power over recognition of foreign governments. Id. at 2086.

${ }^{27}$ See, e.g., U.S. Const. art. I, § 8.

${ }^{28}$ See, e.g., Curtis A. Bradley \& Trevor W. Morrison, Historical Gloss and the Separation of Powers, 126 Harv. L. Rev. 411, 414-15 (2012) (analyzing the role of acquiesced-in government practices in the context of separation of powers).

${ }^{29}$ See, e.g., Wildavsky, supra note 14, at 7-14 (arguing that, among other reasons, foreign policy engages fewer clear partisan preferences than domestic matters and requires expertise the public does not tend to have, and thus Congress tends to cede to the President a freer hand on such matters).

${ }^{30}$ Terry M. Moe \& William G. Howell, Unilateral Action and Presidential Power: A Theory, 29 Presidential Stud. Q. 850, 855-56 (1999).

${ }^{31}$ Patricia M. Wald \& Jonathan R. Siegel, The D.C. Circuit and the Struggle for Control of Presidential Information, 90 Geo. L.J. 737, 737 (2002). 
"one voice" on the international plane, the President is the likeliest option for holding that mantle. ${ }^{32}$ Some reasons are practical: collective action takes time, and the President is considered to be at least relatively "unitary" and thus can act with dispatch that the other branches do not enjoy. ${ }^{33}$ Moreover, while members of Congress have many tools at their disposal, including the power of the purse, they do not themselves command militaries. ${ }^{34}$ But, Congress being Congress, the most significant reason for congressional listlessness in foreign affairs is likely the political one. Most members of Congress have likely determined that the political costs to engaging in foreign policy are not worth the political benefits and tend to engage in this arena only when they are..$^{35}$

All of this is, of course, a matter of intense scholarly discussion and debate. In addition to disagreement over whether Congress has abdicated its authority over foreign affairs, and whether the President has wrongfully aggrandized his power, scholars have also questioned the extent to which Congress even can rein in the President when it tries to. ${ }^{36}$ Many scholars have rightly noted the difficulties Congress faces in changing the President's course of action in the foreign affairs and national security spaces even when it chooses to legislate constraints. ${ }^{37}$ These concerns are compounded by other public law scholarship questioning the extent to which the President is bound by law generally. ${ }^{38}$

${ }^{32}$ See, e.g., Louis Henkin, Foreign Affairs and the United States Constitution 42 (2d ed. 1996) ("That the President is the sole organ of official communication by and to the United States has not been questioned and has not been a source of significant controversy."); Curtis A. Bradley \& Jack L. Goldsmith, Presidential Control over International Law, 131 Harv. L. Rev. 1201, 1231, 1258 (2018). But see Kristen E. Eichensehr, Courts, Congress, and the Conduct of Foreign Relations, 85 U. Chi. L. Rev. 609, 625 (2018) (discussing the undertheorized reality of congressional communication with foreign nations).

${ }^{33}$ See Bradley \& Morrison, supra note 28, at 438-44 (discussing structural and political impediments to congressional action).

${ }^{34}$ See Martin S. Flaherty, The Most Dangerous Branch, 105 Yale L.J. 1725, 1818 (1996) (discussing the President's longstanding unilateralism in entering war as one reason for presidential dominance).

${ }^{35}$ For an account of when Congress is more likely to engage, specifically on war powers, see William G. Howell \& Jon C. Pevehouse, While Dangers Gather: Congressional Checks on Presidential War Powers 33-49 (2007).

${ }^{36}$ Vermeule, supra note 15 , at 1142 .

${ }^{37}$ David Dyzenhaus, The Constitution of Law: Legality in a Time of Emergency 38-40 (2006); Koh, supra note 14, at 1263-65.

${ }^{38}$ See, e.g., Eric A. Posner \& Adrian Vermeule, The Executive Unbound: After the Madisonian Republic 4-5 (2010) (arguing that the President is constrained not by law but by politics). 
Debates over the foreign affairs power focus primarily on questions of authority over substance: Which body is charged with making major policy decisions about a given question of foreign relations or national security? On that metric, the President does "win" most (even almost all) of the time, at least as a functional matter, even when the Constitution explicitly grants Congress the authority in question. ${ }^{39}$ This is so for many reasons - among them information asymmetries; the ability to act with dispatch; the ability to act at all; and Congress's cost-benefit analysis about the political value of intervening in foreign affairs. ${ }^{40}$

Yet presidential primacy is not the end of the story. That the President can ultimately act does not tell us what the President's course of action will be. Particularly in the foreign affairs realm where novel questions often arise and policy preferences do not necessarily divide neatly along partisan lines ${ }^{41}$ there is often significant room for disagreement even inside the executive branch over what action or policy the President should adopt. And to bring this full circle, Congress has means at its disposal to pressure and shape the nature of those internal debates and decision-making processes.

This is where the foreign affairs debate could benefit from the literature on congressional control over the bureaucracy, which I explore in the Section that follows. Both together inform deeper consideration of the multiplicity of ways actors outside the executive branch, including Congress, shape Presidents' actions and policies, as I explore in this Article.

\section{B. Congressional Control of the Bureaucracy}

There are extensive literatures in both political science and public law scholarship on Congress's interest and efficacy in reining in and otherwise controlling the federal bureaucracy. Much of this literature focuses on domestic matters and often even explicitly brackets off the

\footnotetext{
${ }^{39}$ See Koh, supra note 14 , at 1292 . Authorities that the Constitution delegates directly to Congress, which Congress has then either handed over to the President or largely acquiesced in his encroachment, include the power to declare war and the power to regulate international commerce. Id. at 1297-1305.

${ }^{40}$ See, e.g., id. at 1297-98 (analyzing "legislative myopia" and its effects on congressional acquiescence); Wildavsky, supra note 14, at 7-14.

${ }^{41}$ Wildavsky, supra note 14 , at $7-14$.
} 
foreign affairs or national security bureaucracy. ${ }^{42}$ Yet despite the possibly exceptionalist nature of foreign affairs and national security, many of the dynamics that scholarship on bureaucracy considers have relevance for these fields as well. As I explain below, these literatures provide an important jumping-off point for considering Congress's role in influencing executive branch foreign affairs process and policy.

As in the foreign policy space, scholars of congressional-executive relations generally have long reckoned with, bemoaned, or defended what has appeared to be congressional abdication to the President of greater and greater power. With the rise of the administrative state and the concomitant complexity of modern governance, Congress has increasingly moved from narrow delegations of power to the President to broad delegations that create a significant sphere of discretion within which bureaucrats can act. ${ }^{43}$ One debate in modern scholarship considers the extent to which the result of these broad delegations is an entirely unconstrained, all-powerful President; among those who push this "executive unbound" version of the presidency, there are many who warn of its dangers, and others who view it as essentially a good state of affairs. $^{44}$

Others argue that the presidency is not, as an empirical matter, entirely unconstrained. Scholars have pointed to legislative attempts to rein in the President with substantive law, and the effectiveness of those efforts, even in areas like national security and war where the conventional wisdom says the President has enormous leeway. ${ }^{45}$ They have noted that even when Congress fails to legislate, there are a number of other tools it has at its disposal for making its interests known and influential. ${ }^{46}$ And there is a significant body of scholarship examining the extent to which Congress influences bureaucratic choices through its control over the

\footnotetext{
${ }^{42}$ Some notable exceptions to this gap include Amy B. Zegart, Flawed by Design: The Evolution of the CIA, JCS, and NSC 17 (1999), and Anne Joseph O'Connell, The Architecture of Smart Intelligence: Structuring and Overseeing Agencies in the Post-9/11 World, 94 Calif. L. Rev. 1655, 1658 (2006) (analyzing the efficacy and ideal structure of agency design for optimal national security outcomes in the wake of 9/11).

${ }^{43}$ Kagan, supra note 13, at 2253-54.

${ }^{44}$ Compare, e.g., Dyzenhaus, supra note 37, with Posner \& Vermeule, supra note 38.

45 Jack Goldsmith, Power and Constraint: The Accountable Presidency After 9/11, at 30-35 (2012) (analyzing constraints on presidential power in wartime).

${ }^{46}$ See Chafetz, supra note 22 , at 3.
} 
design of agencies' decision-making structure, rather than through substantive legislation. ${ }^{47}$

Scholars have considered the extent to which Congress engages in "ex ante" controls, like agency design, and "ongoing" controls, like oversight, as a means of managing the bureaucracy, though they debate the purpose of these controls. ${ }^{48}$ Some propose that Congress chooses agency design to ensure that agencies hue to their statutory mandate, to, in effect, "hardwire" them in order to reduce "bureaucratic drift." ${ }^{49}$ Others maintain that politicians design agencies primarily with policy preferences and political purposes in mind, which may connect indirectly to efficiency and good governance to the extent voters are informed on these matters. ${ }^{50}$ This literature intersects with debates on the extent to which congressional attempts at control have any real effect on bureaucratic outcomes, whatever their purpose. ${ }^{51}$

Even scholars who do not necessarily see Congress as providing significant constraints on the executive have pointed to other constraints that rein in presidential prerogative. A burgeoning literature has developed exploring the role of bureaucratic, or administrative,

${ }^{47}$ Mathew D. McCubbins, Roger G. Noll \& Barry R. Weingast, Administrative Procedures as Instruments of Political Control, 3 J.L. Econ. \& Org. 243, 244 (1987).

${ }^{48}$ David Epstein \& Sharyn O’Halloran, Delegating Powers: A Transaction Cost Politics Approach to Policy Making Under Separate Powers 25-29 (1999).

49 Jonathan R. Macey, Organizational Design and Political Control of Administrative Agencies, 8 J.L. Econ. \& Org. 93, 93 (1992) [hereinafter Macey, Organizational Design and Political Control] ("[P]oliticians who establish administrative agencies can manipulate the structure and design of those agencies in ways that reduce the chance that future changes in the political landscape will upset the terms of the original understanding among the relevant political actors."); Jonathan R. Macey, Separated Powers and Positive Political Theory: The Tug of War Over Administrative Agencies, 80 Geo. L.J. 671, 671-72 (1992) ("The goal of Congress is to ensure that administrative agencies generate outcomes that are consistent with the original understanding that existed between Congress and the various interest groups that were parties to the initial political compromise.").

${ }^{50}$ David E. Lewis, Presidents and the Politics of Agency Design: Political Insulation in the United States Government Bureaucracy, 1946-1997, at 3, 161-62 (2003) ("[C]alculations about the 'proper' design of administrative agencies are shaped less by concerns for efficiency or effectiveness than by concerns about reelection, political control, and, ultimately, policy outcomes."); Terry M. Moe, The Politics of Bureaucratic Structure, in Can the Government Govern? 267, 267 (John E. Chubb \& Paul E. Peterson eds., 1989) (“American public bureaucracy is not designed to be effective. [It] arises out of politics, and its design reflects the interests, strategies, and compromises of those who exercise political power.").

${ }^{51}$ Christopher R. Berry \& Jacob E. Gersen, Agency Design and Political Control, 126 Yale L.J. 1002, 1017-20 (2017). 
constraints reining in the President from inside the executive branch. ${ }^{52}$ But there is work yet to be done in considering the extent to which congressional process controls on agency structure and design interact with these constraints on the President from inside the executive branch. ${ }^{53}$

As I have explored in prior work, bureaucratic constraints on the President can play a significant role in shaping the process and outcome of executive branch decision making, ${ }^{54}$ but they are created, bolstered-

\footnotetext{
${ }^{52}$ I have previously written about these internal constraints, including most recently in Rebecca Ingber, Bureaucratic Resistance and the National Security State, 104 Iowa L. Rev. 139, 144 (2018) [hereinafter Ingber, Bureaucratic Resistance] (analyzing several distinct categories of "resistance" inside the executive, among and between different sets of actors, and the role of bureaucratic resistance in the separation of powers). See also Neal Kumar Katyal, Internal Separation of Powers: Checking Today's Most Dangerous Branch from Within, 115 Yale L.J. 2314, 2318 (2006) (finding bureaucratic constraints on presidential power wanting); Gillian E. Metzger, 1930s Redux: The Administrative State Under Siege, 131 Harv. L. Rev. 1, 7 (2017) (arguing that the administrative state is a necessary and required constraint on presidential power); Gillian E. Metzger, The Interdependent Relationship Between Internal and External Separation of Powers, 59 Emory L.J. 423, 439-42 (2009) (analyzing the advantages of internal separation of powers mechanisms); Jon D. Michaels, An Enduring, Evolving Separation of Powers, 115 Colum. L. Rev. 515, 520 (2015) (arguing that the administrative state plays a central role in the current separation of powers); Trevor W. Morrison, Constitutional Alarmism, 124 Harv. L. Rev. 1688, 1716-20 (2011) (reviewing Bruce Ackerman, The Decline and Fall of the American Republic (2010)) (describing the work of the Office of Legal Counsel as a constraint on the President).

53 Political scientist James Lindsay, who has written extensively on congressional involvement in foreign policy making, is one of the rare scholars to consider the role of congressional influence on process in the executive branch's foreign policy decision-making space. In his view, scholarship has "underestimate[d]" congressional influence on foreign policy in part because "[p]olitical scientists [were] slow to recognize how process shapes policy." See James M. Lindsay, Congress and Foreign Policy: Why the Hill Matters, 107 Pol. Sci. Q. 607, 616, 619-20 (1992) (discussing the influence of "[s]tructural and procedural innovations" on policy, but noting that the efficacy of these innovations is difficult to answer due to the "understudied" and "slippery" nature of the subject, which involves "anticipated reactions and counterfactuals"); see also James M. Lindsay \& Randall B. Ripley, How Congress Influences Foreign and Defense Policy, in Congress Resurgent: Foreign and Defense Policy on Capitol Hill 17, 17-18 (1993) (describing how Congress retains some influence over foreign and defense policy). Lindsay and Ripley catalog five different types of what they call "procedural legislation," including variations of agency design, reporting, and certification requirements, and "enfranchis[ing] new groups in the decision-making process." Id. at 28-30. Lindsay and Ripley do not examine the designation of or shift in executive branch decision maker as a targeted tool of congressional control, but each of the statutory mechanisms they discuss might be deployed as a means of designating or changing the decider over a particular policy matter, as I explore in Part II.

54 Ingber, Bureaucratic Resistance, supra note 52, at 144; Ingber, Interpretation Catalysts, supra note 19, at 362, 370; Rebecca Ingber, The Obama War Powers Legacy and the Internal Forces that Entrench Executive Power, 110 Am. J. Int'l L. 680, 680-81 (2016) [hereinafter Ingber, The Obama War Powers Legacy].
} 
and can ultimately be undermined - by political sources, like Congress and the President himself, as well as by courts. Beyond agency design, Congress has numerous "hard" and "soft" tools at its disposal for structuring and restructuring the process of decision making inside the executive branch. ${ }^{55}$ And it deploys these tools for purposes in addition to, and beyond that of, bureaucratic responsiveness to political pressure alone, as I explore in this Article.

The foreign policy and national security spaces provide an especially valuable lens for considering this interaction between Congress and bureaucratic constraints, as there are numerous conflicting interests inside the executive branch foreign policy and national security infrastructure, with overlapping jurisdictions, and thus many levers to push and pull to influence decision making. Moreover, novel issues arise or boil over at a higher rate than in the purely domestic policy realm, providing new "policy windows" for Congress and the President to consider matters with fresh eyes. ${ }^{56}$

Drawing on these literatures, this Article considers a range of mechanisms through which Congress shapes executive branch decision making and thus the path of U.S. foreign policy. I focus in particular on a set of process controls that are not theorized in scholarship on the administrative state - the choice of internal executive branch decision makers - and consider the purposes, efficacy, and risks of this tool of congressional administration over the nation's foreign policy.

\section{Process Controls as ToOls of Foreign Policy}

As I describe in Part I, Congress has, for a range of reasons, fallen short in the foreign affairs arena. Whether it holds a significant body of formal power that it refuses to use, or is in fact formally impotent in this sphere,

\footnotetext{
${ }^{55}$ I borrow here the terms "hard" and soft" as applied to congressional power from Professor Josh Chafetz, who in turn borrowed them from international relations theory. See Chafetz, supra note 22, at 3 (describing two forms of congressional power: "hard" power to "coerce," such as the "power of the purse," and other "soft" tools, such as internal rules of discipline and proceedings).

56 John W. Kingdon, Agendas, Alternatives, and Public Policies 165-68 (2d ed. 1995); Jordan Tama, Presidential-Congressional Relations in Foreign Policy, in Rivals for Power: Presidential-Congressional Relations 217, 218 (James A. Thurber \& Jordan Tama eds., 6th ed. 2018) (noting the differences between foreign and domestic policy as a matter of partisan division); Wildavsky, supra note 14, at 7-14 (stating, unpresciently, that "although any president knows he supports foreign aid and NATO, the world outside changes much more rapidly than the nation inside").
} 
there is general agreement on this: Congress does not aggressively legislate a substantive foreign policy agenda, and it certainly does not do so at the expense of its domestic interests. This Part demonstrates, however, that even as Congress often declines to pursue a substantive foreign policy agenda directly, it can and does pursue an array of "process controls" to influence the conduct of foreign affairs short of directing which positions the President should adopt.

I use the term "process controls" here to encompass a range of mechanisms Congress can and does deploy to manage executive branch decision making. These include agency design and administrative procedure requirements, as well as less familiar mechanisms like switching the decision maker inside the executive branch. Process controls permit members of Congress to influence the process and direction of executive branch decision making indirectly, often with a light touch, avoiding many of the pitfalls and political costs members may fear would arise from more direct engagement in foreign policy making. Moreover, process controls may even at times be more effective than direct substantive legislation; ${ }^{57}$ while executive branch officials might seek to interpret their way out of more substantive legislative constraints in order to protect presidential power, process controls commandeer executive branch officials and processes themselves to serve as internal constraints on the President. ${ }^{58}$

Scholarship on the effects of agency design and administrative procedure tends to focus on "political control" over the bureaucracy, a term used to refer to the responsiveness and accountability of bureaucratic actors to politicians, be they in Congress or the Oval Office. ${ }^{59}$ Does the bureaucracy, in so many words, continue to make decisions that those political actors who empowered them would want them to take? Yet process controls can be animated by multiple purposes, beyond policy preference. At times, in fact, the precise purpose for which members of Congress may propose or support a particular mechanism is to remove decisions from political control, and specifically from the intransigence of partisan politics.

\footnotetext{
${ }^{57}$ See infra Section III.B (discussing the efficacy of process controls).

${ }^{58}$ See Ingber, Bureaucratic Resistance, supra note 52, at 145.

${ }^{59}$ See, e.g., David E. Lewis, The Politics of Presidential Appointments: Political Control and Bureaucratic Performance 6-7 (2008); Max Weber, Bureaucracy, in From Max Weber: Essays in Sociology 196, 232 (H.H. Gerth \& C. Wright Mills eds., 1948); Berry \& Gersen, supra note 51 , at $1006-07$.
} 
The choice of process control often connects to the reason members of Congress may have for choosing this tool over another, more direct form of policy engagement. Measures aimed at removing decisions from partisan politics, for example, may be deployed if members of Congress believe it is important to act on a particular matter, but they believe that political sensitivities stand in the way of action unless they give the matter to technocrats. ${ }^{60}$ Creating decision-making pathways inside the executive branch allows members to shift the political burden off their shoulders and onto those of technocrats who are free of such constraints. ${ }^{61}$ At other times, by contrast, members may have specific policy preferences, but may be reticent to act because of high political costs; they may see deploying process controls as a way to effectuate or at least approximate their preferences while shifting the cost burden. Even when their goal is a preferred policy objective, members may believe they can more effectively implement that policy through the use of these measures. They may even choose these tools over more direct substantive legislation mandating a particular policy for reasons of good government. They may actually believe that the executive branch holds the upper hand due to its expertise, or information, or ability, and yet nevertheless have views on improving the process to effectuate better policies. And of course, as Congress is itself anything but a monolith, any given measure that Congress implements may be driven forward by multiple motivations, varying among the members who propose and support it. ${ }^{62}$

This Part seeks to classify these different process controls according to their form and function. I first address two forms of congressional control over the bureaucracy that have been the subject of significant political science and administrative law scholarship-agency design and administrative procedure requirements - to consider how these measures are and can be deployed as tools of foreign policy. But the focus of this Part is the dissection of what I term "designated deciders": measures that shift the decision maker horizontally, such as from one agency head to another, or vertically, upward toward a cabinet official, or downward toward a technocrat; measures that excise responsibility and place it in a

\footnotetext{
${ }^{60}$ See, e.g., Epstein \& O'Halloran, supra note 48, at 2 (discussion of base closures).

${ }^{61}$ Id. at 9.

${ }^{62}$ See, e.g., Kenneth A. Shepsle, Congress Is a "They," Not an "It": Legislative Intent as Oxymoron, 12 Int'l Rev. L. \& Econ. 239, 248, 254 (1992) (arguing that legislative intent is "nonsense" and that "[w]e do not know why [a bill passed], and it is likely that each legislator has a mix of different reasons").
} 
new body, at a distance removed from existing decision makers; and measures that diffuse responsibility among several decision makers inside the executive branch. I classify these process controls here, and consider their purposes, efficacy, and risks in Part III.

\section{A. Foreign Policy Through Institutional Design}

A great deal of political science and administrative law scholarship has been devoted to considering agency design as a tool for political control of the bureaucracy. ${ }^{63}$ Much of this literature is devoted to specific ex ante creation decisions, such as agency independence from the President as measured by a single vector: control over appointment and removal of the agency's leadership. ${ }^{64}$ This focus has less salience in the foreign policy and national security arenas, where presidential power over the bureaucracy is arguably at its peak. Informal norms of independence for some specific areas such as intelligence and law enforcement do exist, as do occasional, narrowly tailored attempts at congressionally mandated independence in these spheres, though the constitutionality of removing these powers from presidential control remains a matter of hot debate. ${ }^{65}$ But agency independence is not the primary vector along which Congress exerts influence in the foreign policy and national security arena. It is thus

\footnotetext{
${ }^{63}$ Epstein \& O'Halloran, supra note 48, at 9; Lewis, supra note 59, at 2-10; Berry \& Gersen, supra note 51, at 1017; Moe, supra note 50, at 268; Macey, Organizational Design and Political Control, supra note 49, at 100 ("[T] he politicians who create administrative agencies can limit future agency costs not only by establishing procedural and substantive rules under which such agencies must operate, but also through the initial organizational design of the agency itself.").

${ }^{64}$ See Berry \& Gersen, supra note 51, at 1012 ("The President's ability to influence the bureaucracy ... . depends on a range of institutional features, including whether the agency's leadership is insulated from presidential removal, the location of the agency inside or outside the cabinet hierarchy, and the extent of presidential appointments in the agency, subject (or not) to Senate approval."); see also Lewis, supra note 59, at 28 ("Congress, at times, tries to circumscribe the president's influence with commissions instead of administrations, fixed terms for appointees, qualifications for appointees, and location outside the cabinet.").

${ }^{65}$ See Morrison v. Olson, 487 U.S. 654, 659-60 (1988) (upholding the constitutionality of an independent counsel); Bruce A. Green \& Rebecca Roiphe, Can the President Control the Department of Justice?, 70 Ala. L. Rev. 1, 5 (2018) (arguing that "prosecutorial independence" is in fact "built into the structure of American government"); Daphna Renan, Presidential Norms and Article II, 131 Harv. L. Rev. 2187, 2207 (2018). Morrison is considered by many to be anti-canon. See Adrian Vermeule, Morrison v. Olson Is Bad Law, Lawfare (June 9, 2017, 8:14 PM), https://www.lawfareblog.com/morrison-v-olson-bad-law [https://perma.cc/964BDTN6]. But see Jamal Greene, The Anticanon, 125 Harv. L. Rev. 379, 394 \& n.80 (2011).
} 
worth considering the foreign policy implications of other aspects of agency design.

Congress is involved in the institutional design of the foreign policy and national security infrastructure from top to bottom. Most of the agencies and offices are, of course, created by legislation, ${ }^{66}$ and Congress has thus been the critical player in creating most of the structures that have engaged our foreign policy since the Founding. ${ }^{67}$ That Congress chose to lodge so much power in the presidency through the establishment of, for example, a Secretary of State and executive agency engaged in foreign affairs - the Department of State - wholly subordinate to the President right from the beginning might suggest congressional acquiescence in the executive's foreign affairs predominance. ${ }^{68}$ But Congress's role in the institutional design of foreign policy does not begin and end with that initial creation of a federal agency. Rather, Congress continues to remain involved through both the regular creation-or termination-of offices within these agencies, through the designation of personnel, including their employment status and relationship to the President, and through the earmarking of appropriations to agencies and offices. ${ }^{69}$

At times of great upheaval or controversy, Congress has engaged this particular tool aggressively to restructure the foreign policy or national security institutions of the U.S. government. After World War II,

\footnotetext{
${ }^{66}$ Some, like the National Security Agency (NSA), are executive branch creations. See George F. Howe, An Early History of the NSA 11, https://www.nsa.gov/Portals/70/documents/news-features/declassified-documents/cryptologic-spectrum/early_history_nsa.pdf [https://perma.cc/TPB2-FRRH]. Some, like the Department of Homeland Security (DHS), begin as executive branch creations, in this case within the White House, and are later ratified and created as a full agency through subsequent legislation. Homeland Security Act of 2002, 6 U.S.C. $\$ 111$ (2002).

${ }^{67}$ The State Department was the first executive branch agency, created as the Department of Foreign Affairs, in 1789. John Jay had been appointed the Secretary of State for Foreign Affairs under the Articles of Confederation and served from 1784 until 1789. A Short History of the Department of State: Diplomacy Under the Articles of Confederation, U.S. Dep't of State, https://history.state.gov/departmenthistory/short-history/articles [https://perma.cc/AZ2Z-4RV6] (last visited Oct. 28, 2019). Thomas Jefferson became the first Secretary of State in 1789, under the new legislation. Administrative Timeline of the Department of State, U.S. Dep't of State, https://history.state.gov/departmenthistory/timeline/1789-1899 [https://perma.cc/ZF3V-UXSA] (last visited Nov. 23, 2019).

${ }^{68}$ Prakash \& Ramsey, supra note 25, at 300 (arguing that in creating this new Department that was entirely beholden to the President, "Congress had cut itself out of the picture").

${ }^{69}$ See, e.g., 22 U.S.C. § $2651 \mathrm{a}$ (f) (2018) (requiring the establishment of "a Coordinator of United States Government Activities to Combat HIV/AIDS Globally ...to operate internationally to carry out prevention, care, treatment, support, capacity development, and other activities for combatting HIV/AIDS").
} 
Congress reorganized the bureaucracy of warfighting and intelligence through the National Security Act of 1947 and subsequent statutes, creating the National Security Council (NSC), the Central Intelligence Agency (CIA), and other offices responsible for intelligence sprinkled throughout the executive branch national security establishment, as well as consolidating the armed services and civilian components of war into one department, the Department of Defense (DOD) ${ }^{70}$ And Congress has re-engaged in ways both small and big, including in response to the Church and Pike Committees, and again after 9/11, to restructure the intelligence community to rein in perceived excesses and resolve perceived deficiencies. ${ }^{71}$

Often, Congress acts in conjunction with the President to engage in shared foreign policy goals. Even within that context, negotiations over precisely how to structure an agency or which programs to fund provide members of Congress - and especially members of the relevant committees-with a means to influence executive policy making, including by narrowing executive requests even while agreeing to delegate power. ${ }^{72}$

But at times, Congress engages its design tools in ways that directly oppose the sitting President's prerogatives, sometimes favoring specific bureaucrats within the rest of the executive branch. This takes many forms, including refusals to fund a presidential priority, which would have a direct effect on the President's policy making by entirely or partially

\footnotetext{
${ }^{70}$ National Security Act of 1947, 50 U.S.C. $\$ \S ~ 3001,3004,3021,3035$ (2018). Professor Amy Zegart has critiqued Congress's design of these agencies, arguing that poor design has led to major substantive policy failures. See Zegart, supra note 42 , at 8 .

${ }^{71}$ S. Rep. No. 94-755, at III, IX (1976) (recommending, in the Final Report of the Senate Select Committee to Study Governmental Operations with Respect to Intelligence Activities, structural changes to the intelligence community in the wake of abuses during the Watergate era). The House undertook its own investigation, through the Pike Committee, though its final report was released only through subsequent leaks. See Intelligence Reform and Terrorism Prevention Act of 2004, Pub. L. No. 108-458, § 102, 118 Stat. 3638, 3644 (2004) (creating the Office of the Director of National Intelligence to oversee the executive branch Intelligence Community); Gerald K. Haines, The Pike Committee Investigations and the CIA, CIA (June 27, 2008), https://www.cia.gov/library/center-for-the-study-of-intelligence/csi-publications/csi-studies/studies/winter98_99/art07.html\#rft0 [https://perma.cc/5D95-P47S].

${ }^{72}$ See, e.g., David Abramowitz, The President, the Congress, and Use of Force: Legal and Political Considerations in Authorizing Use of Force Against International Terrorism, 43 Harv. Int'l L.J. 71, 73 (2002) (discussing congressional pushback against executive branch requests for an even broader grant of authority than what Congress ultimately enacted in the Authorization for Use of Military Force (AUMF) of 2001).
} 
impeding it. ${ }^{73}$ It also includes the opposite: refusals to cut funding to agencies or offices that Congress deems important, thus continuing the work of bureaucrats within those agencies in disregard of the President's preferred approach. One prominent recent example from the past few years is Congress's repeated pushback against the Trump administration's aggressive proposals to cut the State Department budget, initially by $28 \% .{ }^{74}$ During budget hearings in front of the House and Senate Committees in 2017, members of Congress excoriated then-Secretary Rex Tillerson's proposed cuts as exhibiting poor foreign policy judgment and potentially endangering national security. ${ }^{75}$ More important than the rhetoric, Congress ultimately passed a spending bill that refused the proposed budget cuts, instead making only modest cuts from 2017 levels. ${ }^{76}$

General appropriations and the creation of executive offices can be both blunt and sharp instruments. In the broadest sense, Congress is

${ }^{73}$ See Ike Skelton National Defense Authorization Act for Fiscal Year 2011, Pub. L. No. 111-383, § 1032, 124 Stat. 4137, 4351 (2011) (prohibiting the use of funds to "transfer, release, or assist in the transfer or release to or within the United States, its territories, or possessions of Khalid Sheikh Mohammed or any other detainee who . . is or was held on or after January 20, 2009, at United States Naval Station, Guantanamo Bay, Cuba," thus preventing the executive branch from pursuing criminal trials in the United States); see also infra notes 89-102 and accompanying text (discussing National Defense Authorization Acts passed during the Obama administration that conditioned funding for the closure of Guantanamo on the Secretary of Defense certifying that the national security was not impaired due to the release or transfer of a detainee).

${ }^{74}$ Rex W. Tillerson, FY 2018 Congressional Budget Justification Secretary's Letter, U.S. Dep't of State (May 23, 2017), https://www.state.gov/plans-performancebudget/international-affairs-budgets/fy-2018-international-affairs-budget/ [https://perma.cc/5R5G-P7SR]; Ronan Farrow, Inside Rex Tillerson's Ouster, see also New Yorker (Apr. 19, 2018) https://www.newyorker.com/books/page-turner/inside-rex-tillersons-ouster [https://perma.cc/RC5J-MQ3P].

75 The FY 2018 Foreign Affairs Budget, Hearing Before the H. Comm. on Foreign Affairs, 115th Cong. 1-3 (2017) (statement of Rep. Edward Royce, Chairman, H. Comm. on Foreign Affairs); Carol Morello \& Anne Gearan, Senators Sharply Question State Department Budget Cuts, Wash. Post (June 13, 2017), https://www.washingtonpost.com/world/national-security/tillerson-argues-state-departments-main-focus-should-be-on-us-security/2017/06/13/0438ebdc-503f-11e7-be25-3a519335381c_story.html?utm_term=.df96264f3e8c [https://perma.cc/HLN3-6X2S].

${ }^{76}$ Consolidated Appropriations Act, 2018, Pub. L. No. 115-141, Div. K., 132 Stat. 348, 833-971 (2018); see Consolidated Appropriations Act, 2017, Pub. L. No. 115-31, Div. J., 131 Stat. 135, 589-724 (2017). Notably, the bill included aid for programs that the Trump Administration had proposed severely cutting. Julie Hirschfeld Davis, Spending Plan Passed by Congress Is a Rebuke to Trump. Here's Why, N.Y. Times (Mar. 22, 2018), https://www.nytimes.com/2018/03/22/us/politics/trump-government-spending-bill.html [https://perma.cc/BT2Y-HMGY]. 
creating the fora in which foreign policy decision making occurs, and by insisting on funding the State Department, for example, at levels similar to recent history, Congress makes clear that it intends the executive branch to continue to use the "soft" power of diplomacy alongside the "hard" power of military force. But such appropriations themselves can also include more directed tools-for example, the 2018 fiscal bill included foreign assistance for HIV programs that the Trump administration had wanted to cut, specifically ensuring the continuation of an office devoted to policy objectives contrary to the President's. ${ }^{77}$

The existence of a building and offices with funding alone does not direct policy outcomes, of course, but members of Congress are well aware that individual agencies have distinct mandates and that personnel tend to gravitate toward offices and agencies that match their priorities. Thus, privileging funding for, say, the State Department will prioritize a different set of policy goals - specifically diplomacy, soft power, and foreign aid - than would privileging funding for the Department of Defense. Creating the fora for particular types of decision making and ensuring that they remain populated with personnel devoted to a particular mandate creates path dependencies and presumptions that favor continuity of particular policy objectives and hurdles to significant change. And at the other extreme, the defunding or closure of particular offices can have a significant impact on the executive branch's ability to engage a particular area or policy objective. When Congress allocates funding to or away from particular agencies and offices, it privileges certain personnel and certain kinds of decision making over others, and this will shape policy outcomes.

\section{B. Foreign Policy Through Administrative Procedure}

Scholars of administrative law and political science have considered Congress's ability to control the executive branch through the imposition of administrative procedures, in particular the Administrative Procedure Act (APA), which mandates procedures through which executive branch agencies must make certain decisions. ${ }^{78}$ The APA itself largely exempts from its application the executive branch's foreign policy and national

77132 Stat. at 844-46; ONE, Red Ribbon or White Flag? The Future of the U.S. Global AIDS Response 7-8 (Nov. 29, 2017), https://s3.amazonaws.com/one.org/pdfs/ONE_WAD_Report_2017.pdf [https://perma.cc/6J6K-ADE4].

${ }^{78}$ See, e.g., McCubbins et al., supra note 47, at 243, 246. 
security decision making. ${ }^{79}$ But Congress imposes a variety of procedural requirements outside of the APA on the foreign policy and national security decision making of the executive branch - such as requirements that the executive branch certify that specific criteria are met before it can act to, say, provide aid to a foreign nation; ${ }^{80}$ or that it make a finding in writing before it may take covert action; ${ }^{81}$ or that the President report regularly to Congress on his use of military force. ${ }^{82}$

Scholars of political science and economics McCubbins, Noll, and Weingast suggest that Congress turns to administrative procedures as a means of ensuring congressional control over the bureaucracy because of the sheer impossibility of controlling every decision that the bureaucracy makes. ${ }^{83}$ In other words, administrative procedures are a second-best alternative for members of Congress who would otherwise seek to control the substance of decision making directly. As I explore in this Article, however, there are multiple reasons - beyond the sheer scale of decisions that must be made - that Congress might turn to process over substance as a means of influencing policy, and this may be exacerbated in the foreign policy context where Congress is even less inclined to legislate substance than it is in the domestic sphere.

Scholars have considered the extent to which specific procedures have a real effect on government outcomes. Many have argued that certification requirements, for example, are not effective in constraining presidential decision making. ${ }^{84}$ As I discuss in Part III, however, the efficacy of any given process control depends on a variety of factors, including context and the relevant actors, and must be weighed against the likelihood of the alternatives, respectively, inaction or substantive congressional legislation.

A significant body of work applying principles of administrative law to foreign policy and national security focuses not on the efficacy of specific administrative procedure requirements, but on the extent to which

\footnotetext{
${ }^{79}$ Administrative Procedure Act, 5 U.S.C. $§ 553(a)$ (2018) (exempting "military or foreign affairs function of the United States"). And the Supreme Court has held that the President is not covered by the APA. Franklin v. Massachusetts, 505 U.S. 788, 789 (1992).

${ }^{80}$ See Mark A. Chinen, Presidential Certifications in U.S. Foreign Policy Legislation, 31 N.Y.U. J. Int'l L. \& Pol. 217, 221 (1999); Stephen B. Cohen, Conditioning U.S. Security Assistance on Human Rights Practices, 76 Am. J. Int'l L. 246, 247 (1982).

8150 U.S.C. $\$ 3093(\mathrm{a})(1)(2018)$.

8250 U.S.C. $\S 1543$ (c) (2018).

${ }^{83}$ McCubbins et al., supra note 47, at 244.

${ }^{84}$ Chinen, supra note 80 , at 233-35.
} 
the executive branch should be afforded deference on matters of war and national security. ${ }^{85} \mathrm{~A}$ thorough discussion of the role of courts in influencing policy through their allocation of power inside the executive branch is outside the scope of this Article, but it is the subject of a forthcoming project. Suffice it to say here that statutory process requirements are interwoven with judicial review - they are a means by which Congress can more effectively commandeer the courts to help it oversee and influence executive branch policy making, and to do so without necessarily seeking direct responsibility over the policy itself.

\section{Foreign Policy Through Designated Deciders}

The primary focus of this Part is a third category of process control that has received little attention in scholarship: the designation or modification of executive branch decision maker as a means of influencing policy.

The choice of decider is a process control connected to, and at times deployed through the use of, agency design and administrative procedures. It is a highly tailored tool, and can have a significant, targeted effect on the policy positions of the U.S. government. Members of Congress may seek to deploy this measure for multiple purposes: to advance a particular policy objective, to depoliticize particular decisions or prioritize expertise, or to constrain the President. They may seek to institutionalize a particular decision-making process long term, perhaps for purposes of more efficient governance, ${ }^{86}$ or they may seek to advance specific short-terms goals, by, for example, designating a particular decision maker inside the executive branch who they believe holds views more in line with their policy preferences than the alternative deciders. ${ }^{87}$ These purposes may and do overlap; moreover different members of Congress may be compelled by different motivations in supporting the same control measure.

${ }^{85}$ See, e.g., Harlan Grant Cohen, Formalism and Distrust: Foreign Affairs Law in the Roberts Court, 83 Geo. Wash. L. Rev. 380, 384-85 (2015); Deborah N. Pearlstein, After Deference: Formalizing the Judicial Power for Foreign Relations Law, 159 U. Pa. L. Rev. 783, 784-86 (2011); Eric A. Posner \& Cass R. Sunstein, Chevronizing Foreign Relations Law, 116 Yale L.J. 1170, 1173, 1177-78 (2007); Ganesh Sitaraman \& Ingrid Wuerth, The Normalization of Foreign Relations Law, 128 Harv. L. Rev. 1897, 1904-05 (2015); Cass R. Sunstein, Administrative Law Goes to War, 118 Harv. L. Rev. 2663, 2664 (2005).

${ }^{86}$ See infra Subsection II.C.3 (discussing the use of process controls as a means of effectuating military base closures).

${ }^{87}$ See supra notes 1-10 and accompanying text (detailing the Trump Administration's use of Section 232 as a justification for imposing tariffs). 
The choice of decision maker may take different functional forms, each of which may be usefully deployed for different specific purposes and hold different advantages and risks - to transparency, accountability, and effectiveness in meeting a particular purpose. Some process controls shift decision-making authority up to a high-level official, which may increase transparency but may also politicize decision making. Other process controls shift deciders horizontally, which could result in a major policy change if the substitution occurs between decision makers who hold opposing views. And still others diffuse decision making among different deciders or allocate it downward to technocrats and career officials. This Section dissects and classifies this form of process control according to function. I then consider the advantages, efficacy, and risks involved in deploying process controls in Part III.

\section{Vertical Shift in Decider}

One process control that Congress deploys is to shift decision-making authority up or down the hierarchy within the executive branch. This designation may take the form of a delegation of authority to a particular agency head, but other procedural tools - such as a certification requirement, waiver authority, or reporting obligation-may each be deployed as a means of channeling decision-making authority in a particular office, or of shifting decision-making authority further down the chain of command. This category of process control may be deployed for the purpose of promoting a particular policy objective by advantaging a favored agency or official, constraining presidential prerogative, or ensuring that a particular agency's expertise is deployed in a decisionmaking process. It could also be motivated by an interest in increasing accountability for a particular type of decision. ${ }^{88}$ Shifting decisionmaking authority up to, say, the head of an agency, or even to the President, might be done for the purpose of increasing accountability for a matter or raising its profile in the public eye. Shifting authority down, by contrast, might be done for the purpose of taking a matter out of the hands of the President, and, if shifted to career bureaucrats, of setting a decision at a remove from partisan politics or of ensuring expertise is prioritized in the process.

Congressional responses to then-President Barack Obama's pledge to shutter the military detention facilities at Guantanamo Bay provide an

\footnotetext{
${ }^{88}$ See infra Section III.A (discussing purposes for congressional use of process controls).
} 
example of both types of vertical shifts - a shift away from presidential control as well as away from anonymous bureaucratic decision making through the imposition of specific certification requirements on a particular executive branch official, here the Secretary of Defense.

A brief history is necessary for background: Obama's predecessor, President George W. Bush, who first turned to the naval base at Guantanamo as a location for military detention facilities in the conflict with al Qaeda, himself ultimately asserted a policy of closing the detention facilities. ${ }^{89}$ Nevertheless, Obama became inextricably linked with the closure effort, as he made it a campaign pledge while running for President and as one of his very first actions in office issued an executive order commanding its closure within a year. ${ }^{90}$ To do so, he established working groups that would review the case for detention and recommend disposition (transfer, release, or continued detention) for each detainee at Guantanamo. ${ }^{91}$

Opposition to this plan soon grew in Congress, with many members calling for the facility to remain open..$^{92}$ Beginning in 2010, members of Congress attached to the defense appropriations bill onerous restrictions on the President's ability to transfer detainees from facilities abroad. ${ }^{93}$ Rather than simply mandate that Guantanamo remain open, either by prohibiting the use of funds to close it (as Congress ultimately $\operatorname{did}^{94}$ ), or by denying funds for transfers full stop (as Congress also ultimately did for several countries ${ }^{95}$ ), Congress enacted requirements that the Secretary of Defense make rigid certifications about the security threat of any

\footnotetext{
${ }^{89}$ See Jack Goldsmith, The Bush Administration Wanted to Close GTMO Because (in Part) of its Propaganda Value to Jihadists, Lawfare (Feb. 5, 2015, 8:31 PM), https://www.lawfareblog.com/bush-administration-wanted-close-gtmo-because-part-itspropaganda-value-jihadists [https://perma.cc/6WTY-SRX8] (citing President George W. Bush as stating that the detention facility had become a recruiting tool for al Qaeda, and thus that he had "worked to find a way to close the prison without compromising security").

${ }^{90}$ Review and Disposition of Individuals Detained at the Guantánamo Bay Naval Base and Closure of Detention Facilities, Exec. Order No. 13,492, 74 Fed. Reg. 4,897, at $\$ 3$ (Jan. 27 , 2009).

${ }^{91}$ Id. at $\S 4$.

${ }^{92}$ See infra note 99.

${ }^{93}$ See, e.g., National Defense Authorization Act for Fiscal Year 2012, Pub. L. No. 112-81, $\S 1028,125$ Stat. 1298, 1567-69 (2011); Ike Skelton National Defense Authorization Act for Fiscal Year 2011, Pub. L. No. 111-383, § 1033(b)(5), 124 Stat. 4137, 4352 (2011).

${ }_{94}$ National Defense Authorization Act for Fiscal Year 2017, Pub. L. No. 114-328, § 1035, 130 Stat. 2000, 2391 (2016).

95 National Defense Authorization Act for Fiscal Year 2016, Pub. L. No. 114-92, § 1033, 129 Stat. 726, 968-69 (2015).
} 
transfer thirty days before it could occur. ${ }^{96}$ Among the requirements, these provisions mandated that before a detainee could be transferred to a foreign country, the Secretary of Defense, with the concurrence of the Secretary of State, must certify that the government in question

has agreed to take effective steps to ensure that the individual cannot take action to threaten the United States, its citizens, or its allies in the future; [and] has taken such steps as the Secretary determines are necessary to ensure that the individual cannot engage or reengage in any terrorist activity. ${ }^{97}$

The result of this designation was that Congress took functional decision-making authority out of the hands of a panel of career executive branch officials from national security offices throughout the executive branch, as dictated by executive order, and funneled it more squarely and transparently into the (reluctant) hands of the Secretary of Defense. ${ }^{98}$

There may have been multiple purposes animating Congress's deployment of this process control: certainly some members held strong policy preferences in favor of keeping the detention facilities at Guantanamo open, and placing constraints on transfers was a means to that end. ${ }^{99}$ These preferences may have been motivated by, or simply coincided with, the views of some within the national security bureaucracy inside the government, who reportedly opposed closure of the facilities and made those views known-including through regular reports on broadly defined detainee recidivism - to members of Congress. ${ }^{100}$ Other members may have held less strongly formed views

$96 \S 1028,125$ Stat. at $1567-69 ; \S 1033(\mathrm{~b})(5), 124$ Stat. at 4352.

$97 \S 1033(\mathrm{~b})(4)-(5), 124$ Stat. at 4352 (emphasis added).

98 Exec. Order No. 13,567, 3 C.F.R. $\S \S 3$, 9(b) (2011) (designating a "Periodic Review Board" of senior officials from the Departments of State, Defense, Justice, and Homeland Security, the Offices of the Director of National Intelligence, and the Chairman of the Joint Chiefs of Staff to review the continued detention of Guantanamo detainees). The Secretary of Defense was charged with coordinating the review and, along with the Secretary of State, was responsible for the safe transfer of detainees who did not meet the standard for continued detention. Id. at $\S \S 3,4$.

99 Katie Glueck, Graham: Gitmo's “Crazy Bastards,” Politico (Nov. 30, 2012), https://www.politico.com/story/2012/11/sen-lindsey-graham-calls-guantanamo-baydetainees-crazy-bastards-084449 [https://perma.cc/44SA-U57V]; Mitch McConnell, There Are No Good Alternatives to Guantanamo, Wash. Post (Mar. 15, 2009), http://www.washingtonpost.com/wp-dyn/content/article/2009/03/13/AR2009031302907.html [https://perma.cc/6TQK-Q9YW].

${ }^{100}$ See Aziz Z. Huq, The President and the Detainees, 165 U. Pa. L. Rev. 499, 544-54 (2017) (positing that bureaucratic resistance to Obama may have been a driving force behind 
on keeping Guantanamo open, and might not have supported a substantive bill to that effect, but were willing to support - or felt they could not oppose-provisions requiring that the Defense Secretary certify that transfers out of the prison were not a threat. ${ }^{101}$

Whatever the motivations of various members of Congress in deploying this process control, it appears to have had a significant effect on the substantive policy of Guantanamo closure. By designating the Secretary of Defense as the decider in this context, and not just the decider but the public face of the determination, Congress harnessed the reticence of the Secretary of Defense to make such certifications and placed its thumb on the scale on the side of those within the Department of Defense and elsewhere in the executive branch who opposed closing the facility in internal conflict over Guantanamo transfers. ${ }^{102}$ With the certification requirements in place, the flow of detainees from Guantanamo slowed to a near halt. ${ }^{103}$

\section{Horizontal Shift in Decider}

Congress may at times seek to shift decision-making authority from one official inside the administration to another at the same rank, such as from one head of an agency to another. This process control may be motivated by a policy agenda, if, for example, there is a belief that one individual's policy views may be preferable to another's. Or the implementation of such a control may simply reflect a view that a particular office is better suited for such decisions, or that the public may perceive that to be the case.

legislative efforts to halt transfers); Ingber, The Obama War Powers Legacy, supra note 54, at 685-86; Connie Bruck, Why Obama Has Failed to Close Guantánamo, New Yorker (July 25, 2016), https://www.newyorker.com/magazine/2016/08/01/why-obama-has-failed-to-closeguantanamo [https://perma.cc/MEU7-ZKDG] (discussing opposition to closing Guantanamo within the Department of Defense).

${ }^{101}$ See, e.g., infra note 166 and accompanying text.

102 Bruck, supra note 100 (quoting a senior defense official as stating that the certification requirements changed the internal debate, whereas previously, due to the Administration's "focus on closing Guantánamo-you risked your job if you weren't on board," the statutory requirements gave officials "the ability to be openly in favor of transferring people but unable to do it, because of the law").

103 Jennifer K. Elsea \& Michael John Garcia, Cong. Research Serv., R42143, Wartime Detention Provisions in Recent Defense Authorization Legislation 30 (Mar. 14, 2016), https://fas.org/sgp/crs/natsec/R42143.pdf [https://perma.cc/M83P-7BLQ] (acknowledging the slowdown but asserting agnosticism as to the reason). 
An example of a horizontal shift is the changing placement of decisionmaking authority over tariffs, and specifically the national security justification for imposing tariffs, that I discuss in the Introduction. Section 232 of the Trade Expansion Act of 1962, as amended, currently authorizes the President to impose restrictions on imports if the Commerce Secretary, in consultation with the Secretary of Defense, finds them necessary to mitigate a threat to national security. ${ }^{104}$ Recent communications between the Commerce and Defense Secretaries in accordance with this legislative requirement unearthed concerns by thenSecretary of Defense James Mattis that tariffs proposed by the President and supported by the Commerce Secretary would exacerbate, rather than resolve, national security concerns. ${ }^{105}$ Perhaps hoping to leverage the Pentagon's caution in this area, several bipartisan groups in Congress have proposed bills that would amend Section 232 to place more direct authority squarely in the hands of the Defense Secretary to constrain the President from imposing tariffs under this provision. ${ }^{106}$

Congress does not turn to process controls to influence trade policy and constrain the President out of a want of formal authority to direct United States trade policy itself. The Constitution gives to Congress, not the President, the power to regulate commerce with foreign nations. ${ }^{107}$ That the President today holds significant power to impose tariffs is the result of a series of expanding congressional delegations, delegations that Congress could roll back, but thus far has not. ${ }^{108}$

And yet, Congress has repeatedly deployed process controls as a means of influencing trade policy instead of dialing back delegations of authority, even at times deploying these controls alongside expansions of

\footnotetext{
10419 U.S.C. $\S 1862$ (2018).

${ }^{105}$ See Letter from Mattis to Ross, supra note 4 (expressing skepticism that the tariffs at issue were necessary to national security and concerns that they could instead strain relationships with allies).

${ }^{106}$ See supra notes 10-11 and accompanying text; see also Press Release, Sen. Doug Jones, Sens. Jones, Portman, Ernst Introduce Bipartisan Legislation to Reform National Security Tariff Process \& Increase Congressional Oversight (Aug. 1, 2018), https://www.jones.senate.gov/newsroom/press-releases/senators-jones-portman-ernst-introduce-bipartisanlegislation-to-reform-national-security-tariff-process-and-increase-congressional-oversight [https://perma.cc/NA2M-YY23] (stating that placing the decision authority over the national security justification directly in the hands of the Defense Secretary would "ensure that the statute is used for genuine national security purposes" (emphasis added)).

${ }^{107}$ U.S. Const. art. I, § 8, cl. 3.

108 See infra notes 109-10.
} 
such delegations. ${ }^{109}$ In fact, the horizontal shift contemplated by these recent bills is a frequently deployed move for Congress as a means of influencing U.S. trade policy. Congress has already shifted the decision maker for this particular tariff justification about four times, give or take, since it began delegating control over tariffs to the executive branch in the Smoot-Hawley Tariff Act of 1930 - from a series of offices within the White House, to the Treasury Department, to the Commerce Department, and now it may well move the authority again, to the Department of Defense. ${ }^{110}$

The history of Congress's horizontal shifts in decision maker aligns with - and can be partially explained by - an evolution in Congress's policy preferences on trade vis-à-vis the President throughout this period. The relative positions of the President and Congress have shifted dramatically in the Trump administration from previous political contexts when Congress deployed these controls. At the time of the Smoot-Hawley Tariff Act of 1930, it was Congress looking to restrict imports as a means

\footnotetext{
${ }^{109}$ As an example, in 1934, Congress expanded the President's power to enter into trade agreements and adjust tariffs in conjunction with those agreements. An Act to Amend the Tariff Act of 1930, Pub. L. No. 73-316, 48 Stat. 943 (1934). The stated intention of the Act at the time was to empower the President to reduce tariffs quickly in the midst of the Great Depression, in accordance with powers held by executives in other states. H.R. Rep. No. 1000, at 5 (1934). Twenty years later, while continuing to extend this authorization, Congress enacted the first version of the national security justifications for tariff adjustment with the intention of providing industries an opportunity to petition for tariff protection. Trade Agreements Extension Act of 1955, ch. 169, § 7, 69 Stat. 162, 166 (1955); 101 Cong. Rec. 5298 (1955) (noting benefits associated with having a single director in charge who would be responsive to industry).

${ }^{110}$ See, e.g., Omnibus Trade and Competitiveness Act of 1988, Pub. L. No. 100-418, § 1501, 102 Stat. 1107, 1257-60 (1988) (maintaining Commerce Department authority over Section 232 of the Trade Expansion Act but requiring consultation with the Department of Defense); Trade Act of 1974, Pub. L. No. 93-618, § 127(d), 88 Stat. 1978, 1993-94 (1975) (shifting power from the Office of Emergency Planning to the Department of Treasury); Trade Expansion Act of 1962, Pub. L. No. 87-794, § 232(b), 76 Stat. 872, 877 (1962) (shifting power from the Office of Military and Civilian Mobilization to the Office of Emergency Planning); Trade Agreements Extension Act of 1958, Pub. L. No. 85-686, § 8, 72 Stat. 673, 678-79 (1958) (moving power to the Office of Civilian and Defense Mobilization); Trade Agreements Extension Act of $1955 \S 7$ (lodging the power in the Office of Defense Mobilization). At times, these changes simply reflected changes in name or combining of offices by the executive. See, e.g., Reorganization Plan No. 1 of 1958, 23 Fed. Reg. 4991 (July 1, 1958) (combining offices to create the Office of Civilian and Defense Mobilization). But Congress played a role in each shift-reorganization plans gave Congress the opportunity to reject the transfers of office, but Congress instead ratified them. See, e.g., S. Rep. No. 96-402, at 24 (1979) (approving of the transfer of authority from the Treasury Department to the Commerce Department).
} 
of protecting domestic industry, and the President seeking the flexibility to increase or decrease tariffs. ${ }^{111}$ Smoot-Hawley established a series of tariffs and empowered a body called the Tariff Commission, whose members were appointed by the President with the advice and consent of the Senate, ${ }^{112}$ to report to the President on the need to adjust them, giving the President the authority to approve those recommended changes as necessary. ${ }^{113}$ Subsequent statutes expanded the President's authority to adjust tariffs, and the 1955 Extension of Trade Agreement Authority first codified the national security justification, requiring the Director of the Office of Defense Mobilization (an office within the White House) ${ }^{114}$ to investigate national security concerns with imports and report to the President, who was then permitted to adjust imports in accordance with the report after he conducted his own independent investigation. ${ }^{115}$ After additional extensions, ${ }^{116}$ Congress codified the national security exception in the 1962 Trade Act and changed the title of the responsible

111 Tariff Act of 1930, ch. 497, § 330(a), 46 Stat. 590, 696-697 (1930); H. Rep. No. 71-7, at 3 (1929) ("Speaking generally, [tariffs have] served the country well. The past six years have been years of unprecedented development.... However, many new products have entered the markets since 1922, new conditions have arisen in production, new and active competitors have entered the field, the duties on some goods ... as provided in the tariff of 1922 ... were placed too low.”); see also 71 Cong. Rec. 1748 (1929) (statement of Rep. Beck) (arguing against a flexible tariff provision because a President could "summarily reduce tariff rates at a rate so rapid and bewildering that a great many manufacturers in this country will rue the day when they ever vested such power in a single functionary"). For his part, President Hoover, while nevertheless defending protectionism, argued for a more limited and flexible tariff power, one not necessarily opposed to reducing them in appropriate circumstances. Herbert Hoover, Message from the President of the United States, H.R. Doc. No. 71-1, at 1, 4 (1929) (noting that "I have called this special session of Congress to redeem two pledges given in the last election - farm relief and limited changes in the tariff" and arguing that "[i]n determining changes in our tariff we must not fail to take into account the broad interests of the country as a whole, and such interests include our trade relations with other countries. It is obviously unwise protection which sacrifices a greater amount of employment in exports to gain a less amount of employment from imports"). President Hoover concluded by stating that "[s]even years of experience have proved the principle of flexible tariff to be practical, and in the long view a most important principle to maintain." Id. at 4-5.

112 The Commission itself was created in a separate earlier act. Revenue Act, Pub. L. No. 64-271, § 700, 39 Stat. 756, 795 (1916). At the time, however, the Commission filled an investigatory and advisory role, with little power to alter existing tariff rates. Id. $§ 706$.

113 Tariff Act of 1930 §30(a).

${ }^{114}$ The Office of Defense Mobilization was created during the Truman administration. Exec. Order No. 10193, 15 Fed. Reg. 9031 (Dec. 19, 1950) (creating office and designating the appointment procedure of advice and consent by the Senate).

115 Trade Agreements Extension Act of 1955 \$ 7.

116 Trade Agreements Extension Act of 1958, Pub. L. No. 85-686, § 8, 72 Stat. 673, 678-79 (1958) (extending temporary authorization). 
office to the Director of the Office of Emergency Planning to align with the name change within the White House. ${ }^{117}$

The legislative history provides some context for the decision to deploy these controls to place some decision-making authority over the national security justification in the hands of this White House office. In particular, there was a sense among members of Congress and industry lobbyists that obligating this office to issue a report would be more, not less, likely to result in a decision to impose tariffs than placing the power with the President directly, either because the President might himself be opposed, or because taking the explicit authority away from the Director of the Office of Emergency Planning would empower other stakeholders inside the executive branch - namely the State Department - who might have reasons, such as diplomatic concerns, to oppose tariffs. ${ }^{118}$ In fact, representatives from affected industries hoping to convince the President to levy tariffs testified before Congress to this effect, arguing in favor of keeping the reporting requirement with the Office of Emergency Planning. ${ }^{119}$ A representative of the textile industries testified that the

117 Trade Expansion Act of 1962, Pub. L. No. 87-794, § 232(b), 76 Stat. 872, 877 (1962). The name change was effectuated in response to a request from President Kennedy, who had transferred much of the authority of the Office of Civil and Defense Mobilization to the Department of Defense. See Office of Emergency Planning Establishment Act, Pub. L. No. 87-296, 75 Stat. 630 (1961) (codifying change of name to the Office of Emergency Planning). This name was again altered in 1968 to the Office of Emergency Preparedness. See Supplemental Appropriation Act, 1969, Pub. L. No. 90-608, § 402, 82 Stat. 1190, 1194 (1968).

${ }_{118}$ See, e.g., Trade Expansion Act of 1962: Hearings Before the H. Comm. on Ways and Means on H.R. 9900 Part 5, 87th Cong. 3063 (1962) [hereinafter Hearings, Part 5] (statement of Eugene Stewart, Counsel, Man-Made Fibre Producers Association, Inc.); id. (statement of Rep. Baker) ("So, in effect, if we enact [the 1962 Trade Expansion Act] without amendment in this field, we will have repealed the national security provision of existing law."); Trade Expansion Act of 1962: Hearings Before the H. Comm. on Ways and Means on H.R. 9900 Part 4, 87th Cong. 2715-16 (1962) [hereinafter Hearings, Part 4] (statement of Harry B. Purcell, Vice President, The Torrington Company) ("To leave to the sole determination of the person who occupies the White House which tariff cuts would or would not 'threaten to impair the national security' would be sheer folly."); see also S. Rep. No. 100-82, at 18 (1987) (describing overall changes in trade policy during this period and noting that "the State Department was criticized for sacrificing U.S. trade interests for other foreign policy concerns").

119 Hearings, Part 4, supra note 118, at 2715-16 (statement of Harry B. Purcell, Vice President, The Torrington Company) ("To leave to the sole determination of the person who occupies the White House which tariff cuts would or would not 'threaten to impair the national security' would be sheer folly."); see also Trade Expansion Act of 1962: Hearings Before the H. Comm. on Ways and Means on H.R. 9900 Part 3, 87th Cong. 1460 (1962) (statement of Donald J. Hawthorne) (arguing in favor on behalf of the watch industry); id. at 1569, 157778 (statement of Ralph Frey) (arguing in favor on behalf of the watch industry); id. at 1723 
State Department was in fact "resisting a finding by the Office of Civil and Defense Mobilization, now called the Office of Emergency Planning, that imports of textiles are threatening to impair the national security."120 Were Congress to remove that office from the language of the statute, the representative worried, the President might not choose to request their advice, out of concern that "a favorable finding in the national security case by the Office of Civil and Defense Mobilization ... would cause some inconvenience so far as diplomatic relations with foreign countries." 121 Instead, such a statute "would facilitate the ease with which the State Department can subvert and oppose and prevent favorable findings in these national security cases." 122 In other words, industry professionals believed that despite the Office of Emergency Planning's placement inside the White House, a reporting requirement placed on that office would be more likely to compel the President to levy tariffs than were the same substantive delegation made to him directly, because he might in that case prioritize the views of other actors inside the executive branch, namely the State Department. ${ }^{123}$

Over subsequent amendments, Congress continued to shift the decider over the national security justification, changing the designation first to the Secretary of the Treasury, ${ }^{124}$ when the Office of Emergency Planning was abolished, ${ }^{125}$ and then to the Secretary of Commerce. ${ }^{126}$ At one point, industry representatives, particularly the precision ball bearing industry, lobbied Congress to shift the authority to the Defense Department, based on suggestions that Defense officials would have been more favorable to

(statement of John H. Lichtblau) (arguing to keep the procedure and limit the time permitted for reports). But see id. at 1820 (statement of Otis H. Ellis, General Counsel, National Oil Jobbers Council, Inc.) (arguing against the national security justification); id. at 1380-81 (statement of Charles W. Engelhard) (arguing that the defense provision is a "cloak for the narrowest protectionist pressures").

${ }^{120}$ Hearings, Part 5, supra note 118, at 3063 (statement of Eugene Stewart, Counsel, Fibre Producers Association, Inc.).

${ }^{121} \mathrm{Id}$.

122 Id.

${ }^{123}$ Id.

124 Trade Act of 1974, Pub. L. No. 93-618, § 127(d), 88 Stat. 1978, 1993-94 (1975).

${ }^{125}$ Reorganization Plan No. 1 of 1973, § 3, 38 Fed. Reg. 9579 (1973) (disbanding the office and transferring powers held by the office to the Treasury Department).

${ }^{126}$ Reorganization Plan No. 3 of 1979, § 5(a)(1)(B), 44 Fed. Reg. 69273, 69274 (1979); see also Omnibus Trade and Competitiveness Act of 1988, Pub. L. No. 100-418, § 1501, 102 Stat. 1107, 1257-1260 (1988); Trade Act of $1974 \S 127(d)$. 
industry interests in promoting tariffs. ${ }^{127}$ One member of Congress vociferously argued in favor of shifting the authority to DOD, and suggested that the Deputy Secretary of Defense and other executive branch officials shared this belief. ${ }^{128}$ Ultimately, Congress landed on a compromise solution and amended Section 232 to require that the Treasury Secretary, and later the Secretary of Commerce, consult with and receive an assessment from the Secretary of Defense. ${ }^{129}$

Many of these shifts appear to have been prompted at least in part by an interest in meeting the concerns of industry officials who hoped to prompt the President to levy, rather than to constrain, tariffs on particular industries, in a context where he was deemed unlikely to do so were he granted the authority unilaterally. Today we find the policy preferences reversed: the President is inclined to use his delegated authorities to impose tariffs, and Congress appears to be seeking ways to constrain him. ${ }^{130}$ In both of these contexts, however, members of Congress have turned to process controls rather than changes to substantive delegations of power in order to effectuate their preferences. ${ }^{131}$

127 Tariff and Trade Proposals Part 12: Hearings Before the H. Comm. on Ways and Means, 91st Cong. 3345-50 (1970) (statement of Rep. James C. Cleveland).

128 Id.

129 Trade Act of $1974 \S 127(d)$. The requirement of consultation with the Department of Defense continued into the next iteration of the national security justification. Omnibus Trade and Competitiveness Act of $1988 \S 1501$. The decision to lodge the power exclusively in the Secretary of Treasury and then the Commerce Department, rather than the Department of Defense, appears to be due to concerns about access to necessary economic data. Threat of Certain Imports to National Security: Hearing Before the S. Comm. on Fin., 99th Cong. 2426 (1986) (statement of Sen. Byrd) ("The Commerce Department has much of the economic data on American industries and the scope of foreign imports; but this is not a conventional trade question. The language of the statute makes it clear that the threat of injury to national security must be assessed after weighing many factors, many of them within the expertise of the Department of Defense.").

${ }^{130}$ Nevertheless, concerns regarding the potential abuse of Section 232 were voiced by congressmembers at the time of the passage of these various amendments, but they were largely overridden by a belief in the prudential nature of the executive office. See, e.g., H.R. Rep. No. 93-571, at 199 (1973) (minority views) ("There is no question that this bill would make the President of the United States the foreign trade czar of this Nation."); see also Press Release, Sen. Rob Portman, supra note 11 (noting recent bipartisan congressional efforts to limit Section 232 power).

131 See Press Release, Sen. Rob Portman, supra note 11 (arguing that delegation to the Department of Defense rather than the Department of Commerce would effectuate the goals of Section 232). 


\section{Excision of Decision-Making Responsibility and Power}

At times Congress may seek to create new entities as a means of placing decision making at a remove from existing options. Congress's handling of the impasse over military base closures in the late 1980s by creating a new commission to make the necessary decisions is a prime example of congressional excision of decision making.

In the wake of the Vietnam War, after the Department of Defense under President Kennedy closed over sixty military bases, decisions to close military bases became politically fraught. The Department of Defense was determined to cut costs by eliminating "underutilized" bases, and yet closing any given military base entailed a sure loss of jobs, raising the profile of base closures on the domestic policy agenda for Congress. ${ }^{132}$ Congress passed legislation increasingly involving itself in base closure decisions, ultimately in 1977 mandating that they approve all large base closures. ${ }^{133}$ Yet voting for base closure was a political hot potato; no politician could support closing a military base in his or her own district. ${ }^{134}$ As a result, it became nearly impossible for the Department of Defense to close military bases, at significant cost. ${ }^{135}$

Ultimately, in response in part to changing politics, budgetary concerns, and lobbying efforts by the Department of Defense, the concept of closing military bases gained support in Congress, at least in theory. ${ }^{136}$ But the question remained how to make that happen considering the domestic political costs. Delegating the decision directly to DOD did not resolve the political question, as the Secretary of Defense was himself a political appointee. ${ }^{137}$ The solution - proposed by DOD and adopted by Congress - was to delegate decisions about base closures to a bipartisan commission appointed by the Secretary of Defense that would report both

132 Def. Sec'y's Comm'n on Base Realignment \& Closure, Base Realignments and Closures: Report of the Defense Secretary's Commission 6-8, 29 (Dec. 1988) (on file with author) [hereinafter 1988 BRAC Report]; Epstein \& O'Halloran, supra note 48, at 1-4.

13310 U.S.C. $\$ 2687$ (2018) (originally enacted as Pub. L. No. 95-82, tit. VI, § 612(a) (1977)) (requiring congressional approval for "the closure of any military installation at which at least 300 civilian personnel are authorized to be employed").

1341988 BRAC Report, supra note 132, at 8-9; Epstein \& O’Halloran, supra note 48, at $1-4$.

1351988 BRAC Report, supra note 132, at 8-9 (noting that "[s]ince passage of this legislation over a decade ago, there has not been a single major base closure").

${ }^{136}$ Epstein \& O’Halloran, supra note 48, at 2.

137 Id. at 3. 
to him and to Congress. ${ }^{138}$ The Secretary of Defense and Congress retained a veto over the ultimate proposal - each could take action to reject the Commission's list in its entirety - but the process allowed them to shift the political costs of choosing a base onto the independent commission, an entity less inclined to feel such costs. ${ }^{139}$

\section{Diffusion of Decision-Making Responsibility and Power}

At other times members of Congress may seek to diffuse decisionmaking responsibility and power, rather than channel it to a decisionmaking body. This may be done through a variety of measures, including concurrent delegations to multiple agencies, requirements of coordination, and mandatory consultation provisions. ${ }^{140}$ Such requirements are fairly common, particularly in the domestic regulatory space, and may be motivated by various purposes. Professors Jody Freeman and Jim Rossi identify several different rationales for overlapping control in their article, Agency Coordination in Shared Regulatory Space, including: turf wars among members of congressional committees; an interest in removing decision making from the President; desire to include multiple spheres of expertise in decision making; compromise; and accident. ${ }^{141}$ To this list I would add an interest in constraining or slowing down presidential action, which is evident in the recent Syria and Republic of Korea bills I discuss in the end of this Subsection. ${ }^{142}$

Since 2017, Congress has used the National Defense Authorization Act (NDAA) to limit the President's ability to conduct bilateral military operations with Russia through fact-finding conditions placed jointly on the Secretaries of Defense and State. Specifically, the statute conditions funding for such bilateral operations on a certification by the Secretary of Defense, in coordination with the Secretary of State, that

\footnotetext{
${ }^{138}$ Defense Authorization Amendments and Base Closure and Realignment Act, Pub. L. No. 100-526, § 202, 102 Stat. 2623, 2627 (1988).

${ }^{139}$ Id. $\S \S 202,208$.

${ }^{140}$ Jody Freeman \& Jim Rossi, Agency Coordination in Shared Regulatory Space, 125 Harv. L. Rev. 1131, 1145 (2012).

${ }^{141}$ Id. at $1138-43$.

142 Professor Bijal Shah considers and classifies congressional mechanisms to force interagency coordination for a range of purposes, including constraint of the President, in an excellent article, Congress's Agency Coordination. See 103 Minn. L. Rev. 1961, 2035-36 (2019).
} 
(1) the Russian Federation has ceased its occupation of Ukrainian territory and its aggressive activities that threaten the sovereignty and territorial integrity of Ukraine and members of the North Atlantic Treaty Organization; and

(2) the Russian Federation is abiding by the terms of and taking steps in support of the Minsk Protocols regarding a ceasefire in eastern Ukraine. ${ }^{143}$

Similarly, Congress recently added to the Defense Appropriations Act a delegation to the United States Cyber Command of the power to undertake proportionate defensive cyber operations against Russia, contingent on "the National Command Authority determin[ing] that the Russian Federation . . . is conducting an active, systematic, and ongoing campaign of attacks against the Government or people of the United States in cyberspace." 144 The National Command Authority is comprised of the President and the Secretary of Defense, and thus a delegation contingent on its determination appears to dilute the delegation of power, at least as compared to a delegation to the President alone. ${ }^{145}$ The ostensible purpose here is to facilitate the Defense Department's ability to undertake these kinds of defensive cyber operations, and the inclusion of the Secretary of Defense as a necessary component of the determination of Russian activity would seem designed to assist in that endeavor. This may well operate to facilitate action in practice, depending on the process the Secretary of Defense and the President have for making National Command Authority decisions. But as a general matter, a mechanism of joint control such as this one, as compared to a delegation to the President alone, could have the effect of constraining action, as it positions the Secretary of Defense as a statutory hurdle to action.

143 National Defense Authorization Act for Fiscal Year 2017, Pub. L. No. 114-328, $\S 1232$ (a), 130 Stat. 2000, 2488 (2016) (amended 2018, 2019). The NDAA 2019 includes a carve-out for "bilateral military-to-military dialogue between the United States and the Russian Federation for the purpose of reducing the risk of conflict." John S. McCain National Defense Authorization Act for Fiscal Year 2019, Pub. L. No. 115-232, § 1247(b)(2), 132 Stat. 1636, 2050-51 (2018).

${ }^{144}$ John S. McCain National Defense Authorization Act § 1642(a)(1).

145 See Robert Chesney, The Law of Military Cyber Operations and the New NDAA, Lawfare (July 26, 2018, 2:07 PM), https://www.lawfareblog.com/law-military-cyberoperations-and-new-ndaa [https://perma.cc/T5TC-S2LY] (taking note of this designation to the "NCA as opposed to just the president" as "[v]ery interesting"). 
Recently, a spate of proposed bills have sought to engage this process control as a means of effectuating a particular policy. In 2018 and 2019, several senators introduced bills to engage several national security agencies in the decision-making process for new sanctions on Russia over its election interference. Senators Marco Rubio and Chris Van Hollen twice proposed a bill-titled the DETER Act - that would place the critical trigger over foreign state sanctions in the hands of the Director of National Intelligence and other intelligence officials - and quite pointedly not the President. ${ }^{146}$ The proposed bill would trigger a requirement that the President - through the Treasury Secretary-impose sanctions on Russia or any other State should the Director of National Intelligence ("in consultation with the Director of the Federal Bureau of Investigation, the Director of the National Security Agency, [and] the Director of the Central Intelligence Agency") make a finding that the State has interfered in American elections. ${ }^{147}$ Unlike the cyber operations provisions of the NDAA, which simply grant authority conditioned on the finding of the National Command Authority, the DETER Act would require action, conditioned on the Director of National Intelligence's finding of fact. ${ }^{148}$

And in January 2019, a bipartisan group in the House introduced two bills aimed at preventing the President from withdrawing troops from the Republic of Korea and Syria through funding limitations. ${ }^{149}$ Neither bill would require that the President keep troops in either Syria or the Korean Peninsula. Instead, each would make funding contingent on executive branch officials meeting certain procedural obligations. ${ }^{150}$ The Syria bill would prohibit the use of funds to withdraw troops from Syria unless the Secretary of Defense, the Secretary of State, and the Director of National Intelligence submit a report to Congress answering sixteen onerous

${ }^{146}$ Defending Elections from Threats by Establishing Redlines Act of 2019, S. 1060, 116th Cong. § 202(a) (2019); Defending Elections from Threats by Establishing Redlines Act of 2018, S. 2313, 115th Cong. § 201(a) (2018).

${ }^{147}$ Defending Elections from Threats by Establishing Redlines Act of $2019 \S \S 101$ (a), 202(a).

148 Id. § 202(a) (stating “[i]f the Director of National Intelligence determines under section 101 that the Government of the Russian Federation ... knowingly engaged in interference in a United States election, the President shall, not later than 30 days after such determination is made, impose the following sanctions").

${ }^{149}$ Responsible Withdrawal from Syria Act, H.R. 914, 116th Cong. (2019); United States and Republic of Korea Alliance Support Act, H.R. 889, 116th Cong. (2019).

${ }^{150}$ Responsible Withdrawal from Syria Act $\S 2(a)$; United States and Republic of Korea Alliance Support Act $§ 2(b)$. 
questions about the state of affairs in Syria. ${ }^{151}$ The Republic of Korea bill is far more aggressive: it prohibits the use of funds to withdraw troops from the Korean Peninsula unless the Secretary of Defense and Chairman of the Joint Chiefs of Staff certify, inter alia, that "the Republic of Korea would be fully capable of defending itself and deterring a conflict on the Korean Peninsula following such a reduction." ${ }^{152}$ Should they pass, these would undoubtedly face some pushback from the President as infringing on his commander-in-chief authority, which I discuss further below. ${ }^{153}$ But historically, Presidents have often chosen to comply with procedural requirements despite raising separation-of-powers concerns, even when such requirements pose a hurdle to their policy agenda. ${ }^{154}$

\section{Implicit Allocations of Decision-Making Power}

In addition to direct, targeted designations of specific deciders, Congress also allocates decision-making authority inside the executive branch implicitly, to unnamed administrators whose work product is required by the terms of the statute. When Congress premises a statutory delegation of power to the President or head of an agency on the condition that certain procedures be followed, facts found, or reports provided to Congress, this implicitly necessitates the involvement of certain types of actors within the executive branch, namely: experts, professionals, technocrats, and lawyers. ${ }^{155}$ The expert class of officials within the executive branch is typically made up of non-politically-appointed civil servants, operating around the middle tiers of the executive branch

\footnotetext{
${ }^{151}$ Responsible Withdrawal from Syria Act $§ 2(a)(1)-(16)$.

${ }^{152}$ United States and Republic of Korea Alliance Support Act § 2(b)(2)(C).

${ }^{153}$ See infra Subsection III.C.1.

${ }^{154}$ See infra notes 182-83 and accompanying text (discussing President Obama's nearly perfect compliance with the Guantanamo certification requirements, which he had critiqued in a signing statement as potentially raising separation-of-powers concerns); see also Matthew C. Weed, Cong. Research Serv., R42699, The War Powers Resolution: Concepts and Practice (2019) (summary) (collecting instances of presidential statements that stated that the President was acting "consistent with" the War Powers Resolution, and finding that "Presidents have submitted 168 reports as the result of the War Powers Resolution, but only one ... cited Section 4(a)(1), which triggers the 60-day withdrawal requirement").

${ }^{155}$ See McCubbins, Noll \& Weingast, supra note 47, at 244 ("[P]rocedures can be used to enfranchise important constituents in agency decisionmaking processes, thereby assuring that agencies are responsive to their interests."). Professors Elizabeth Magill and Adrian Vermeule have written about a similar effect on executive branch decision making of judicial doctrines and process requirements, although their focus was on these doctrines' "upward" allocation of power within agencies. See Elizabeth Magill \& Adrian Vermeule, Allocating Power Within Agencies, 120 Yale L.J. 1032, 1061-62 (2011).
} 
bureaucracy. ${ }^{156}$ Their role is essential to adequately carrying out process requirements like fact-finding or reporting to Congress. Thus, even without explicitly naming an office or official in its delegation of power, Congress can influence the organization of decision making inside the executive branch by legislating process requirements.

Statutory requirements that executive branch officials engage in particular processes, or find specific facts, or explain their actions before acting fall within the "administrative procedures" category I discuss above. ${ }^{157}$ But they are also a vehicle through which Congress can designate deciders by steering power away from the President and toward lower-level officials, even while delegating it to, or accepting its use by, the executive branch as a whole.

\section{IMPLICATIONS OF CONGRESSIONAL ADMINISTRATION}

Congressional influence on foreign affairs through the administration of executive branch decision making has numerous implications-for Congress's ability to influence foreign policy, for transparency and accountability of foreign policy decisions, for the extent to which the President is in fact bound by law_-and it can be judged according to each of these criteria.

When considering these implications and the value of process controls, one must weigh them against the actual alternatives, taking into account the potential for their realization. These alternatives include, on the one hand, more direct involvement of Congress, such as through direct substantive efforts to legislate policy, or, on the other hand, an even starker abdication of influence to the President. Congressional administration can be weighed against those alternatives on two levels: as a descriptive matter (why might members of Congress prefer these forms of engagement to the alternatives) and as a more normative one (whether these forms are advantageous as a matter of policy and whether they raise different or fewer constitutional issues).

${ }^{156}$ Daniel P. Carpenter, The Forging of Bureaucratic Autonomy: Reputations, Networks, and Policy Innovation in Executive Agencies, 1862-1928, at 19-20 (2001); Magill \& Vermeule, supra note 155, at 1067.

${ }^{157}$ See supra Part II. 


\section{A. Why Deploy Process Controls to Influence Foreign Policy}

There are many reasons members of Congress might turn to process controls to influence policy short of mandating its substance. Targeted process controls may permit members of Congress to push past hurdles that would otherwise impede action. They may provide a means of resolving conflicts or promoting a policy that could not be addressed or passed through substantive legislation. At times process controls may even be more efficacious in influencing policy than would substantive legislation seeking to mandate it directly. I explore these reasons in further detail in this Section.

\section{Why Do Process Controls Surmount Congressional Reticence?}

There are numerous reasons Congress does not take full advantage of its foreign affairs power. Some may be based in genuine concern about the relative institutional competence of Congress in this realm as against the executive branch. Such concerns may be based on a belief that the United States should speak with one voice and that voice should be the President's, or deference to the executive branch's relative expertise, access to information, and dispatch. For reasons of expediency and good government, including the interest in presenting a unified United States foreign policy to the world, members of Congress might reasonably take the view that the President and the executive branch are best placed to control foreign policy decision making.

Of course, history suggests that these concerns are not sufficient to compel Congress to sit it out entirely. There have been multiple occasions when members of Congress - both through duly enacted legislation and through separate individual or small group action- have sought to press their own foreign policy objectives. Moreover, they have done so not only when the President has hesitated to act himself, but even in the face of the President's clear, contrary foreign policy goals. Congress's attempt to legislate U.S. recognition of Jerusalem as the capital of Israel is one such example. ${ }^{158}$ For a non-legislative attempt to interfere with the President's foreign policy agenda, consider the "Open Letter to the Leaders of the

\footnotetext{
${ }^{158}$ See, e.g., Zivotofsky v. Kerry, 135 S. Ct. 2076, 2082-84 (2015) (discussing Congress's attempt to grant a right to have a person's place of birth listed as "Jerusalem, Israel," despite the executive branch's longstanding policy not to acknowledge any nation's sovereignty over Jerusalem).
} 
Islamic Republic of Iran," signed by forty-seven Republican senators, opposing President Obama's Iran nuclear deal. ${ }^{159}$

I see no separation-of-powers rationale for distinguishing between these and other foreign policy decisions in which Congress chooses not to challenge the President's agenda. Rather, the distinction is likely to be a political one. In these limited examples, members of Congress found a political advantage to a foreign policy showdown with the President, and little disadvantage. More often, however, there are significant political reasons that Congress declines to take a strong stand in the foreign policy arena. When one or both houses of Congress are held by the same political party as the President, members may find it politically unsavory or inopportune to challenge him generally, especially on foreign policy. ${ }^{160}$ And even when opposing parties control both the House and Senate, members may find it more politically useful to be able to criticize the President's choices than to own a particular foreign policy themselves. They may find that their constituents are not as interested in questions of foreign policy vis-à-vis domestic, and therefore that there is little to be gained politically by engaging directly in this space. ${ }^{161}$ Congressional abdication on foreign policy matters may also have a self-fulfilling, snowballing effect that connects back up to institutional reasons for abdication: as members of Congress sit out major debates on war and foreign policy, they lose (or fail to gain) expertise in these realms. And as Congress has fallen back on foreign policy, the executive branch has been more than willing to fill the void.

Whatever the reason for congressional timidity in the foreign policy realm, congressional administration through process controls provides an alternate vehicle to facilitate congressional influence in this realm, which may avoid some of the stumbling blocks that otherwise hold Congress back.

First, unlike mandating substance directly, shaping foreign policy through the use of process controls enables Congress to exploit, rather

\footnotetext{
${ }^{159}$ Letter From Senate Republicans to the Leaders of Iran, N.Y. Times (Mar. 9, 2015), https://www.nytimes.com/interactive/2015/03/09/world/middleeast/document-the-letter-senate-republicans-addressed-to-the-leaders-of-iran.html?_r=1\&module=inline [https://perma.cc/NW4P-WJCJ].

${ }^{160}$ See Daryl J. Levinson \& Richard H. Pildes, Separation of Parties, Not Powers, 119 Harv. L. Rev. 2311, 2352 (2006).

${ }^{161}$ See, e.g., Howell \& Pevehouse, supra note 35, at 193 ("[M] $[\mathrm{M}$ ost citizens, most of the time, come to foreign policy discussions with fewer well-defined and independently formulated prior beliefs than they do to domestic policy debates ....").
} 
than undermine, the advantages in the foreign policy realm that the executive holds over Congress, such as expertise and access to information. As with other areas of policy making, Congress may quite reasonably acknowledge that it is not-at least as it has evolved - capable of tackling the enormity and complexity of all decisions that the executive branch bureaucracy undertakes. ${ }^{162}$ Process controls thus permit Congress to influence the shape of decisions while benefiting from the vastness and complexity of the bureaucracy, and with it executive branch expertise, information, expediency, and flexibility.

Second, congressional use of process controls may permit members of Congress to influence policy without necessarily damaging the United States' ability to speak with "one voice" in foreign affairs. While that "one voice" may presumptively be the President's, in practice, it has always been the result of executive branch deliberation more broadly. ${ }^{163}$ That Congress may influence the internal dynamics that result in that position does not necessarily undercut the President's stature abroad as the expected mouthpiece for the U.S. government.

Third, it may be easier for proponents of a measure to obtain votes on a bill including a process control than on one compelling a particular substantive policy. Process controls are often attached to broader legislative packages on which members are voting, potentially creating an opt-out versus an opt-in scenario for choosing whether to support the bill. ${ }^{164}$ Moreover, process controls may appear more "neutral" than substantive legislation. ${ }^{165}$ Whereas a substantive provision may engender sufficient support to compel members to vote against it, a process control will be less likely to be a make-or-break component of the bill. ${ }^{166}$

${ }^{162}$ McCubbins, Noll \& Weingast, supra note 47, at 254 (“'A]n important function of administrative procedures is to provide a means of inducing bureaucratic compliance that does not require the time, effort, and resources of political actors.").

${ }^{163}$ See Henkin, supra note 32 , at $41-42$.

164 For example, Congress has embedded process controls in recent National Defense Authorization Acts, forcing members of Congress to choose between voting for the provisions and voting against funding the military. See, e.g., Ike Skelton National Defense Authorization Act for Fiscal Year 2011, Pub. L. No. 111-383, § 1033(a), (b)(5), 124 Stat. 4137, 4351-52 (2011).

${ }^{165}$ See Lindsay \& Ripley, supra note 53, at 28 (“[T]he 'ostensibly neutral' character of procedure makes it easier to build a winning coalition around procedural changes than around substantive policy changes.").

166 See, e.g., David Manners-Weber, Comment, Certification as Sabotage: Lessons from Guantánamo Bay, 127 Yale L.J. 1416, 1442-44 (2018) (discussing interviews with several members of Congress that suggest they voted for process controls that would effectuate a policy that they would not have supported); Dara Lind, Republicans Have Obama in a Corner 
Finally, process controls give members of Congress a means of pushing back against a President even when it could be politically costly to do so more directly. ${ }^{167}$ Adding process requirements to a statutory grant of power or designating a particularly trusted executive branch official as the decision maker on a specific grant of authority is hardly as headlinegrabbing or as conflict-creating as openly legislating a policy contrary to the President's. Moreover, process controls typically leave the politically sensitive decisions in the hands of bureaucrats - whether lower-level technocrats or high-level heads of agencies-permitting members of Congress to avoid or even deny responsibility for the resulting policy should it fail or prove unpopular. Whether the process control delegates to technocrats or to the head of an agency, it permits members of Congress to shift the political costs of decision making to the executive branch, while still retaining some influence over the policy.

\section{Process Controls and Purpose}

Congressional deployment of process controls to influence foreign policy may be motivated by diverse purposes. In fact, any given mechanism of control may be driven by multiple, varied motivations among the members of Congress who supported it. ${ }^{168}$ These motivations

on Syrian Refugees, Vox (Nov. 19, 2015, 2:06 PM), https://www.vox.com/2015/11/1919762054/congress-obama-refugees-syria [https://perma.cc/4KQ3-MFNY] (calling a bill that would slow the process of accepting refugees by requiring certifications by high-level administration officials "anodyne enough that it's attracted broad support from congressional Democrats as well as Republicans").

${ }^{167}$ For a recent example of this effort, see Defending Elections from Threats by Establishing Redlines Act of 2019, S. 1060, 116th Cong. (2019) (bipartisan bill co-sponsored by Sen. Marco Rubio "[t]o deter foreign interference in United States elections"). For anecdotal evidence that congressional members of the same party as the President might not be aware of the potential effects of a given process control, allowing sponsors to pick up votes they might not get with more direct approaches, see Jennifer Steinhauer \& Michael D. Shear, House Approves Tougher Refugee Screening, Defying Veto Threat, N.Y. Times (Nov. 19, 2015), https://www.nytimes.com/2015/11/20/us/politics/house-refugees-syria-iraq.html

[https://perma.cc/22MS-QMLC] (noting that during debates over certification requirements for Syrian refugees, in the face of attempts by then-President Obama to sway Democratic congressional members to vote against the requirements as adding unnecessary hurdles to an already rigorous vetting process, Democratic Representative Sean Patrick Maloney stated, "I started out strongly opposed to [the bill]. ... But then I read the bill and realized that what it actually required was simple certification").

168 Of course, it is not always clear the extent to which members of Congress support particular process controls for a given purpose. See, e.g., Abbe R. Gluck \& Lisa Schultz Bressman, Statutory Interpretation from the Inside-An Empirical Study of Congressional Drafting, Delegation, and the Canons: Part I, 65 Stan. L. Rev. 901, 943, 989 (2013) (revealing 
may include mistrust of the President, conflicting views over the preferred policy objective, or an interest in avoiding political costs for a necessary action.

Process control measures deployed for the purpose of promoting a preferred policy objective may involve a shift of decision maker to an agency or office likely to press policy objectives in line with those of members of Congress, such as the statutory mandate that the Secretary of Defense certify the lack of threat for all transfers out of Guantanamo. ${ }^{169}$ Similarly, recent interest in transferring to the Secretary of Defense authority over the Section 232 national security justification for tariffs appears to be motivated by a desire to minimize the use of that exception. ${ }^{170}$

Measures intended to depoliticize decision making or to advance particular expertise will typically allocate power downward, toward career officials and technocrats within the agency, or to an appointed bipartisan commission, rather than toward the President or his direct appointees. ${ }^{171}$ Congress's creation of a nonpartisan commission to issue military base closure recommendations fulfilled this purpose by taking the political heat off members of Congress, who found votes to close military bases highly unpopular among constituents who would be affected by the loss of jobs and resources. ${ }^{172}$

And measures to combat a lack of trust in the President-whether based on suspicion of corruption or doubts about his judgment in a given area-may deploy any of the above, depending on the extent to which other actors within the executive branch inspire greater confidence. The DETER Act bill discussed above is a prime example; if passed, it would make the Director of National Intelligence (not the President) the arbiter of whether Russia was interfering in U.S. elections, thus triggering the sanctions in the bill. ${ }^{173}$ This would permit Congress and the country to

\footnotetext{
the breadth of motivations and procedural causes behind statutory drafting and the delta between knowledge among the drafters of statutes and assumptions about congressional intent); see also Shepsle, supra note 62, at 248 (discussing the various reasons for legislative preferences, including personal taste, ideology, responsibility to constituents, responsibility to donors, etc.).

${ }^{169}$ See supra Subsection II.C.1 (discussing Guantanamo transfer restrictions).

${ }^{170}$ See supra Subsection II.C. 2 (discussing the multiple historical shifts in authority over the Section 232 justification and recent attempts to shift it again).

${ }^{171}$ See supra Subsection II.C.3 (discussing the creation of an executive branch-based commission to issue recommendations on military base closures).

${ }^{172}$ See supra Subsection II.C.3.

${ }^{173}$ See supra Subsection II.C.4 (discussing the DETER Act).
} 
benefit from the expertise and access to information of the executive branch intelligence agencies, while simultaneously taking some policymaking power away from a President whose motivations in this realm many, including quite possibly the members of his own party who support the bill, have come to suspect. And it would do so without implicating concerns of a so-called "deep state" seeking power at the expense of elected leadership, because the policy objective would come from Congress itself.

\section{B. Efficacy of Congressional Administration}

So does congressional administration in fact influence the shape of foreign policy decision making, or is Congress just rearranging deck chairs on a ship the President will sail in whichever direction he likes? While administrative procedures and agency design are often held out as tools of bureaucratic control, clear accounts of the extent to which these controls are effective, and at producing what particular purpose, are rare. ${ }^{174}$ The few scholars who have considered the role of specific administrative procedures in influencing foreign policy have taken opposing views on their efficacy. ${ }^{175}$

This Section considers the efficacy of process controls-and specifically the choice of decider measures that I discuss in Section II.Cin light of the various purposes for which they might be deployed. This is not an extensive survey of results, nor is it a demonstration of efficacy. Such a study would be worthwhile though complicated; while numerous examples exist in which process controls correlate with a result that accords with purposes I describe above, the reasons for a particular outcome may be overdetermined. There is the problem of "observational equivalence" akin to that faced by scholars seeking to demonstrate that the President makes decisions constrained by law and not policy

\footnotetext{
${ }^{174}$ See, e.g., Berry \& Gersen, supra note 51, at 1009, 1038-39 (using bureaucratic decisions to allocate appropriated funds to measure the political responsiveness of agencies based on design, and finding the common belief - that deploying political appointments throughout an agency makes them more politically responsive - to be consistent with their results).

${ }^{175}$ See, e.g., Chinen, supra note 80, at 235 (arguing that "certification requirements are not particularly effective in controlling executive behavior"). But see Manners-Weber, supra note 166 , passim (arguing that certification requirements can be effective, and that specifically, the Guantanamo certification requirements created an obstacle to Obama closing the detention facility).
} 
preferences that happen to accord with law. ${ }^{176}$ Furthermore, any given process control itself may be motivated by multiple purposes.

Nevertheless, it is possible to deduce from understandings of the inner working of executive branch bureaucracy how the various process controls I describe above may interact with internal levers of decision making, and thus the types of influence they are likely to exert, and why, if not whether, they will in each event result in a change of outcome. I thus examine here the features of congressional administration and contextual factors that are relevant to the inquiry.

\section{The State of Play Inside the Executive Branch}

The state of agreement or conflict inside the executive branch on a particular matter of foreign policy or national security affects the extent to which opportunities exist for congressional administration to influence executive decision making. Foreign policy and national security are fields that engage many different agencies and executive branch offices, with overlapping jurisdictions and often conflicting mandates and biases. ${ }^{177}$ These complexities provide opportunities for influencing outcomes by changing decision-making processes, responsibilities, and authority.

To the extent key actors on the inside are all on one page, and that page is the President's, there are few pressure points for members of Congress to manipulate to do their bidding. Happily for Congress, such extreme agreement among all components of the executive branch is rare. Often on matters of foreign policy and national security there exist serious policy differences either between different agencies or personalities - or both - and the process of decision making inside the executive branch can have a considerable effect on the outcome, in large part because that process affects the weight afforded particular decision makers and who will be the ultimate "decider." 178 In prior work, I have discussed how triggers outside of the executive branch can influence that process and the authority of particular internal "deciders," and thus can help shape the

\footnotetext{
176 See Curtis A. Bradley \& Trevor W. Morrison, Presidential Power, Historical Practice, and Legal Constraint, 113 Colum. L. Rev. 1097, 1114 (2013).

${ }^{177}$ See, e.g., Neomi Rao, Public Choice and International Law Compliance: The Executive Branch Is a "They," Not an "It," 96 Minn. L. Rev. 194, 199-200 (2011) (discussing the "divergent interests" of the "number of legal departments [with] responsibility for international law interpretation"); see also Freeman \& Rossi, supra note 140, at 1176 (describing a "multilevel interagency process" in the national security and defense contexts).

${ }^{178}$ See, e.g., Ingber, Interpretation Catalysts, supra note 19, passim.
} 
ultimate outcomes. ${ }^{179}$ Congress has more power than most to influence that process, and thus, congressional engagement to place a thumb on the scale of one side can have a significant effect on the resulting outcome.

For example, in the case of the Guantanamo transfer restrictions, members of Congress had reason to believe that the Department of Defense, and specifically the Secretary of Defense, would be more reluctant to approve transfers than others within the executive branch, such as the Secretary of State. The reasons for that belief were plentiful: unlike the other relevant decision makers, the Defense Secretary hailed from the President's opposing political party, and the Department of Defense was understood to harbor a significant amount of dissent inside the building (though not universal dissent) regarding the President's plan to shutter the Guantanamo detention facilities. ${ }^{180}$ Members of Congress also hoping to slow Guantanamo closure had their own channels to actors within the Defense Department, and thus were surely aware of internal executive branch conflict over detention questions. ${ }^{181}$

Delegating the requirement to the Secretary of Defense to certify transfers privileged the position of the Department of Defense in those internal debates with the rest of the executive branch. And even though President Obama signed the Act containing the certification requirements with an accompanying signing statement questioning their constitutionality, ${ }^{182}$ he nevertheless continued to comply - through the Secretary of

\footnotetext{
${ }^{179} \mathrm{Id}$.

180 See, e.g., Ingber, Bureaucratic Resistance, supra note 52, at 210-14 (discussing resistance within the Department of Defense to the President's plan to shutter the detention facilities at Guantanamo).

${ }^{181}$ See, e.g., Charles Levinson \& David Rohde, Special Report: Pentagon Thwarts Obama's Effort to Close Guantanamo, Reuters (Dec. 29, 2015, 5:20 AM), https://www.reuters.com/article/us-usa-gitmo-release-special-report-idUSKBN0UB1B020151229 [https://perma.cc/WA5G-X5QY ] (noting friction within the Department of Defense); Rebecca Shabad, Report: Pentagon Officials Have Slowed Process to Close Gitmo, CBS News (Dec. 28, 2015, 5:33 PM), https://www.cbsnews.com/news/report-pentagon-officials-have-slowed-process-to-close-gitmo/ [https://perma.cc/7LWS-RZUF].

${ }^{182}$ See, e.g., Press Release, White House Office of the Press Sec'y, Statement by the President on H.R. 2055 (Dec. 23, 2011), https://obamawhitehouse.archives.gov/the-pressoffice/2011/12/23/statement-president-hr-2055 [https://perma.cc/EK6G-K5U5] (stating that "Congress has also included certain provisions in this bill that could interfere with my constitutional authorities in the areas of foreign relations and national security" and that "I will apply these provisions in a manner consistent with my constitutional authority as Commander in Chief").
} 
Defense - with the reporting and certification requirements. ${ }^{183}$ The result of the new certification requirements was that transfers out of Guantanamo ground almost to a halt in the aftermath of the legislation. ${ }^{184}$

There appear to be similar dynamics at play with the proposed swapping of decision makers over the Section 232 exceptions to tariff rules. Here, again, the President and some members of his cabinet seem inclined toward action - in this case the imposition of significant tariffs on foreign imports across the board - and the former Defense Secretary, James Mattis, was believed to hold views closer to that of many members of Congress, who did not want to see such extreme tariffs imposed broadly. ${ }^{185}$ Members of Congress have had reason to believe, in part due to his own memorandum to this effect, that the former Secretary of Defense, and later after his departure, the Department generally, would be less inclined to certify a national security justification for imposing tariffs than was the Secretary of Commerce. They have thus made a number of attempts to move the authority from the latter to the former. ${ }^{186}$

Congressional reliance on internal tensions may take a short or long view. While any given statutory designation is likely to outlast particular appointees, who come and go quite regularly, interagency tensions are often longstanding and survive administration to administration, and thus specific designations may continue to operate as intended beyond the lifespan of a particular appointee. ${ }^{187}$ Nevertheless, priorities and

\footnotetext{
${ }^{183}$ The only exception was the transfer of five Guantanamo detainees in exchange for Bowe Bergdahl. See U.S. Dep't of Def. Press Operations, Statement on the Transfer of Detainees Before the House Armed Servs. Comm. (June 11, 2014) (delivered by Sec'y of Def. Chuck Hagel) (acknowledging that the transfer occurred without the thirty-day notice required by the statute, but stating that "[t]he President has constitutional responsibilities and constitutional authorities to protect American citizens and members of our armed forces").

${ }^{184}$ See Manners-Weber, supra note 166, at 1424.

185 Letter from Mattis to Ross, supra note 4.

${ }^{186}$ See generally Promoting Responsible and Free Trade Act of 2019, H.R. 3673, 116th Cong. (2019) (requiring "congressional approval of certain trade remedies"); Trade Security Act of 2019, S. 365, 116th Cong. (2019) ("To amend section 232 of the Trade Expansion Act of 1962 to require the Secretary of Defense to initiate investigations and to provide for congressional disapproval of certain actions ...."); Bicameral Congressional Trade Authority Act of 2019, S. 287, 116th Cong (2019); Promoting Responsible and Free Trade Act, H.R. 6923, 115th Cong. (2018) (requiring "congressional approval of certain trade remedies"); Trade Security Act of 2018, S. 3329, 115th Cong. (2018) ("To amend section 232 of the Trade Expansion Act of 1962 to require the Secretary of Defense to initiate investigations and to provide for congressional disapproval of certain actions ....”).

${ }^{187}$ Ingber, Bureaucratic Resistance, supra note 52, at 162-63, 168-69; see Press Release,
} Sen. Rob Portman, supra note 11; see also Rao, supra note 177. 
preferences do shift over time, agency mandates are reorganized, and offices are brought closer to or further from the White House from administration to administration; thus, as with the shifting designations over Section 232 justifications for tariffs, members of Congress may find it useful to shift agency deciders when the current structure no longer comports with their intentions in creating it.

\section{Process Controls: Formal or Functional Barriers?}

A potential challenge to my account of process controls as an effective means of constraining or compelling presidential action is the argument that executive branch actors ultimately report to the President and must do his bidding. Designating a decider within the executive branch may create some paperwork requirements but should not - under this viewaffect the actual policy result, because that is the President's to decide. Whether or not this reflects the formal breakdown of power within the executive branch (and I do not accept that it does, certainly not for all or even most executive branch exercises of power), it does not describe the functional reality, in which decision-making power and process have a significant, if not always dispositive, role in the path of policy making.

Most of the examples of congressional administration I discuss in this paper involve allocations of power to officials over which the President exercises direct removal authority. Scholars differ on the extent to which the removal power is a sufficient political control over bureaucratic autonomy. Under Elena Kagan's view of "Presidential Administration," the President's authority implicitly extends to directing these officials to take a particular action even if it does not accord with their own views. ${ }^{188}$ Their delegated authority is, in other words, really the President's. ${ }^{189}$ Professor Gary Lawson goes several steps further, arguing that the President should have the power to nullify the acts of subordinates. ${ }^{190}$ Professor Kevin Stack takes an opposing view, arguing that the President

\footnotetext{
${ }^{188}$ See Kagan, supra note 13, at 2326-28 (arguing that while the Constitution does not require that the President be able to direct all authority delegated to administrative officials, statutory delegations to such officials, outside of independent agencies, should generally be interpreted as "subject to the ultimate control of the President").

${ }^{189}$ Id. at 2328.

${ }^{190}$ Gary Lawson, The Rise and Rise of the Administrative State, 107 Harv. L. Rev. 1231, 1244 (1994).
} 
does not have authority to direct subordinates in cases where statutes delegate executive power to them specifically. ${ }^{191}$

Even accepting arguendo the most aggressive view of presidential power over subordinates' decisions as a matter of formal authority-and I do not-as a functional matter, process and structure shape decision making and add hurdles, if not barriers, to the President's ability to effectuate his preferred policies. ${ }^{192}$ Consider one glaring example: the President's oft-stated desire during the first half of the Trump administration to end the Russia investigation run first by the FBI under James Comey, and then by the Special Counsel, Robert Mueller. ${ }^{193}$ If the investigation were under his direct, immediate control, it is probably fair to say there can be no doubt that he would have ended or severely compromised it. ${ }^{194}$ But this was not within his immediate power, because the investigation was designed to be situated several steps of personnel removed from the President's control. ${ }^{195}$ In his efforts to end the investigation, he removed some officials, such as FBI Director James

${ }^{191}$ Kevin M. Stack, The President's Statutory Powers to Administer the Laws, 106 Colum. L. Rev. 263, 267 (2006).

192 Kagan herself acknowledges this practical reality. See Kagan, supra note 13, at 2298 ("Their resistance to or mere criticism of a directive may inflict political costs on the President as heavy as any that would result from an exercise of the removal power. This fact of political life accounts in part for the consultations and compromises that prefaced many of the Clinton White House's uses of directive authority. In this context, to put the matter simply, persuasion may be more than persuasion and command may be less than command-making the line between the two sometimes hard to discover.").

193 Donald J. Trump (@realDonaldTrump), Twitter (Aug. 15, 2018, 7:08 AM), https://twitter.com/realDonaldTrump/status/1029731513573822464 [https://perma.cc/MUS6-3HXW] ("The Rigged Russian Witch Hunt goes on and on as the "originators and founders" of this scam continue to be fired and demoted for their corrupt and illegal activity. All credibility is gone from this terrible Hoax, and much more will be lost as it proceeds. No Collusion!”); Donald J. Trump (@realDonaldTrump), Twitter (Nov. 29, 2018, 4:16 AM), https://twitter.com/realDonaldTrump/status/1068116413498429445[https://perma.cc/H875WTP3] ("When will this illegal Joseph McCarthy style Witch Hunt, one that has shattered so many innocent lives, ever end-or will it just go on forever? After wasting more than $\$ 40,000,000$ (is that possible?), it has proven only one thing-there was NO Collusion with Russia. So Ridiculous!”); Donald J. Trump (@realDonaldTrump), Twitter (Aug. 1, 2018, 6:24 AM), https://twitter.com/realDonaldTrump/status/1024646945640525826 [https://perma.cc/VA23-7D9B] (“...This is a terrible situation and Attorney General Jeff Sessions should stop this Rigged Witch Hunt right now, before it continues to stain our country any further. Bob Mueller is totally conflicted, and his 17 Angry Democrats that are doing his dirty work are a disgrace to USA!").

${ }^{194}$ See supra note 193.

195 The regulations governing the special counsel do set the investigation at some remove from the President, but as they are created by executive order and not statute, the President holds formal authority to change them. See 28 C.F.R. § 600.9 (2018). 
Comey and, eventually, Attorney General Jeff Sessions. ${ }^{196}$ But he failed to remove others, such as the Deputy Attorney General, Rod Rosenstein, and Robert Mueller himself, in time to stop the investigation. ${ }^{197}$ Each removal had, or was delayed by, political repercussions, despite the fact that each removal was within his formal authority to effectuate. ${ }^{198}$ And yet he was stymied in his efforts to end the investigation, not primarily by formal legal constraints, though in this case there may also exist some, but by the political hurdles of what ending the investigation would entail and require-likely firing each official who refused to end the investigation until he were to find someone who would. ${ }^{199}$ Thus some officials left, but Rosenstein remained to the end, along with his decisions to commence and to protect the inquiry, despite the fact that the President would not have made those decisions himself. Wherever the formal line is drawn with respect to presidential control over executive branch personnel, presidential control through appointment and removal is hardly equivalent as a functional matter to presidential control over the decision itself.

1962 Robert S. Mueller, III, U.S. Dep't of Justice, Report on the Investigation into Russian Interference in the 2016 Presidential Election 66-68, 107-111 (2019) [hereinafter Mueller Report] (outlining the timelines behind the President's decisions to have FBI Director James Comey and Attorney General Jeff Sessions fired).

${ }^{197}$ Id. at 78, 88-89 (discussing the President's attempts to have the White House Counsel, Don McGahn, fire Robert Mueller and thus terminate the investigation).

198 This is not to say that there are no formal constraints on removal; for example, the President may be subject to constraints on his ability to obstruct justice as a matter of law (if not one addressable by courts at this time), which could constrain his formal authority to fire law enforcement officials for particular purposes. See generally Daniel J. Hemel \& Eric A. Posner, Presidential Obstruction of Justice, 106 Calif. L. Rev. 1277 (2018) (arguing that the President may be held criminally liable for obstructing justice through the corrupt exercise of constitutional powers); Mueller Report, supra note 195, at 1-2 (stating that the investigation was constrained by the 2000 Office of Legal Counsel opinion that states the President cannot be prosecuted for criminal offenses while in office).

${ }^{199}$ It is generally understood that Nixon's "Saturday Night Massacre" series of firings and resignations of Department of Justice (DOJ) officials precipitated his fall. See, e.g., Ron Elving, Nixon's Saturday Night Massacre Casts Shadow as Trump Considers Fate of DOJ Leaders, NPR (Oct. 20, 2018, 7:15 AM), https://www.npr.org/2018/10/20/659032303/nixonssaturday-night-massacre-casts-shadow-as-trump-considers-fate-of-doj-leade [https://perma.cc/FV4E-ZK4H] (pointing to the firings as a cause of his resignation); Amy B. Wang, The Saturday Night Massacre: 'Your Commander in Chief Has Given You an Order,' Wash. Post (May 11, 2017), https://www.washingtonpost.com/news/retropolis/wp/2017/05/11/thesaturday-night-massacre-your-commander-in-chief-has-given-you-an-order/?utm_term=.77268fd3eadc [https://perma.cc/ZX5S-CT42] (same). 


\section{Harnessing of Accountability Mechanisms}

One of the more effective uses of process controls is the placement of public responsibility for a decision directly in the hands of a particular official, who will thus understand herself to be accountable for whichever decision she chooses going forward. When this mechanism is combined with a legal requirement-for example, to find facts or to certify that certain factors are met - this accountability feature raises the stakes for the designated individual choosing whether or not to comply with the substantive legal requirements.

Moreover, a procedural requirement is often less open to interpretation than, say, whether a particular strike qualifies as "war" and whether the President can undertake it without congressional authorization. Presidents tend to avoid actively asserting noncompliance with law, but they may assert an interpretation that some find far-fetched. ${ }^{200}$ And the extent to which a presidential claim is simply a different interpretation or beyond the pale can be particularly hard to police in areas where the law is ambiguous, fraught, or evolving. By contrast, a requirement that the Secretary of Defense sign a piece of paper with specific language or produce a report to Congress provides a much simpler metric by which to judge compliance or non-compliance with law.

By engaging with foreign policy through process controls, Congress enlists these internal actors themselves in its cause. It places the onus on these individuals to decide for themselves whether to comply with or disregard particular statutory obligations, removing their ability to hide behind the President or behind collective action in determining whether a statutory requirement must be followed or whether it is a plausible justification to dismiss the requirement as an unconstitutional encroachment on the President. And while Presidents may be protected to some degree from certain kinds of accountability, such as criminal prosecution while in office, lower-level officials have fewer protections. ${ }^{201}$ Executive branch officials may face both hard and soft forms of personal liability for lawbreaking: from criminal prosecution in some cases, to inspector general or Government Accountability Office

200 See Bradley \& Morrison, supra note 176, at 1114 ("It is rare for Presidents to acknowledge that they are acting inconsistently with the law. Instead, they typically argue that the law does not require what critics are contending.").

${ }^{201}$ Federal government officials do enjoy some immunity from civil liability for decisions they make in their official capacity, but they are not protected for unambiguous lawbreaking. See, e.g., Harlow v. Fitzgerald, 457 U.S. 800, 818 (1982). 
(GAO) investigations, to congressional requests and even subpoenas to testify and explain actions taken, to disbarment or other professional censure, to public and professional embarrassment. ${ }^{202}$ As former Defense Secretary Leon Panetta dramatically explained when pressed on his record of not approving a single transfer out of Guantanamo under the congressional certification requirements, "[T]hat provision required that I sign my life away." ${ }^{203}$ For these reasons and others, executive branch officials who are designated deciders may be more inclined than the President or unnamed groups of advisers or officials to comply carefully with the letter of statutory requirements.

\section{Risks in Congressional Administration}

Congressional administration does not put to bed all debates about the allocation of foreign affairs authority among the branches of the federal government. In fact, precisely because congressional administration may facilitate congressional involvement in areas where members might otherwise choose to sit out, congressional influence over foreign policy through process controls may provide the flashpoint for thorny constitutional questions over the line between the President's and Congress's authorities. Beyond these constitutional risks, there are potential disadvantages to engaging foreign policy through congressional administration. For example, deploying process controls may give members of Congress a false sense of action, mollifying concerns about the President's policy direction or judgment and thus keeping Congress from engaging in substantive policy debates more directly. And process controls might at times undermine, rather than promote, accountability for decision making.

\footnotetext{
${ }^{202}$ Soldiers, for example, must be prosecuted and punished for violating the laws of war. Federal officials face criminal sanction for violating the Anti-Deficiency Act. Agency Inspectors General Offices investigate misconduct by federal employees. The Government Accountability Office (GAO) is an independent agency that investigates wrongdoing on behalf of Congress. See Overview, Gov't Accountability Off., https://www.gao.gov/about/ [https://perma.cc/C3GE-36DN]. Congress also frequently calls executive branch officials to testify in order to explain how their actions comport with statutory requirements. And professional associations are often called upon to censure the actions of professionals accused of acting unethically or otherwise outside the norms of the profession.

${ }^{203}$ Bruck, supra note 100.
} 


\section{Constitutional Risks in Congressional Administration}

Congressional administration of foreign policy and national security raises distinct constitutional issues from the rest of the administrative state, depending on the extent to which a given exercise of control approaches the debated zone between the President's delegated statutory authority and constitutional Article II power. While some level of congressional involvement in the design and ongoing process of executive branch decision making has a long, and executive branchaccepted, pedigree, the executive branch has long bristled at, and often pushed back against, any congressional engagement that interferes with, let alone "prevents," a "constitutionally assigned function[]."204 Considering the sparseness of the text, "constitutionally assigned" may seem a high bar; the Constitution explicitly assigns very little power to the President alone. But the extent to which the President may trump Congress in this space, if at all, is a matter of hot debate. ${ }^{205}$ And congressional attempts to control policy through the bureaucracy itself may raise similar constitutional dilemmas as attempts to dictate that policy directly. Thus congressional involvement in the foreign affairs and national security realms raises significantly thornier questions than similar engagement with other parts of the administrative state, which rely more exclusively and more clearly on delegated authority. ${ }^{206}$

Some examples may help set the lay of the land. Certainly, a congressional attempt to constrain the President's use of his pardon power through, say, a requirement that the Attorney General certify that every pardoned individual is sufficiently contrite, would be impermissible. ${ }^{207}$ The executive branch would likewise likely challenge as unlawful process controls that executive branch officials perceive to be interfering with the

\footnotetext{
204 The Constitutional Separation of Powers Between the President and Congress, 20 Op. O.L.C. 124, 174-75 (1996) (citing Nixon v. Adm'r of Gen. Servs., 433 U.S. 425, 443 (1977)). 205 See supra note 25.

206 See Constitutional Separation of Powers, supra note 204, at 133 n.27 ("Legislation impinging on the President's responsibilities in the areas of foreign affairs and national defense poses unique issues in the application of the general principle of separation of powers, requiring a more searching examination of the validity of congressional action.").

${ }^{207}$ See Schick v. Reed, 419 U.S. 256, 266 (1974) (concluding that the pardon "power flows from the Constitution alone, not from any legislative enactments, and that it cannot be modified, abridged, or diminished by the Congress"). In fact, the federal regulations regulating the pardon process for the executive branch themselves explicitly state that they are "advisory only" and do not "restrict the authority granted to the President under Article II, section 2 of the Constitution.” 28 C.F.R. $\S 1.11$ (2018).
} 
President's ability to exercise his commander-in-chief authority (although the President might nevertheless comply). ${ }^{208}$ Yet the extent to which that clause gives the President any plenary constitutional authority over war, concurrent authority with Congress, or in fact very little non-delegated authority at all, is controversial. ${ }^{209}$ While the Constitution makes the President the "Commander in Chief," it gives to Congress not only the power to declare war but also the power to fund it and to make rules governing the armed forces. ${ }^{210}$ A recent proposal by Professors Richard Betts and Matthew Waxman to mandate certification by specific internal actors, including a legal review by the Attorney General, before the President may order the launch of a nuclear weapon raises precisely these questions. ${ }^{211}$ So, too, it is far from clear whether the congressional requirements that the Secretary of Defense certify Guantanamo transfers, for example, present a constitutional conflict. President Obama suggested as much in signing statements, and even at one point violated the statutory prohibition, but otherwise complied. ${ }^{212}$ Neither matter would likely come before the courts, and because of the executive branch's general track record of compliance with such requirements, both are examples of areas where Congress might effectively rein in the President even without necessarily running to ground the scope of their authority to do so.

Outside of the Commander in Chief Clause and the authority to appoint and receive ambassadors, the President's foreign policy dominance has less clear sourcing, but the executive branch has long sought to claim and

${ }^{208}$ U.S. Const. art. II, § 2; see supra note 204 and accompanying text.

${ }^{209}$ See supra Section I.A.

${ }^{210}$ U.S. Const. art. I, § 8.

${ }^{211}$ Richard K. Betts \& Matthew C. Waxman, The President and the Bomb: Reforming the Nuclear Launch Process, 97 Foreign Aff. 119, 120 (2018).

${ }^{212}$ See Presidential Statement on Signing the National Defense Authorization Act for Fiscal Year 2014, 2013 Daily Comp. Pres. Doc. 876, 1 (Dec. 26, 2013) (stating that "in certain circumstances, [the transfer restrictions] would violate constitutional separation of powers principles"); News Release, U.S. Dep't of Def., Statement from Sec'y of Def. Chuck Hagel on the Return of Sgt. Bowe Bergdahl (May 31, 2014), https://archive.defense.gov/Releases/Release.aspx?ReleaseID=16737 [https://perma.cc/ND5Y-KZKH]; Jack Goldsmith, The President Pretty Clearly Disregarded a Congressional Statute in Swapping GTMO Detainees for Bergdahl, Lawfare (June 2, 2014), https://www.lawfareblog.com/presidentpretty-clearly-disregarded-congressional-statute-swapping-gtmo-detainees-bergdahl [https://perma.cc/8TYE-9674] (discussing the exchange of an American soldier for GTMO detainees, in which the Secretary of Defense did not meet the thirty-day notification requirement in the statute). 
protect it, ${ }^{213}$ often, though not always, successfully. ${ }^{214}$ Yet some areassuch as international commerce-quite clearly lie within congressional control and have been ceded to the executive only through progressive statutory delegations. ${ }^{215}$ Congress could dial back the President's authority in these areas entirely, and thus the fact that it intervenes through process controls rather than through substance should not create any greater constitutional problems than engagement with other areas of the administrative state.

It is also worth at least briefly noting here ongoing debates in scholarship over the extent to which Congress may direct how the executive branch executes the law, in particular, debates over the concept of a "unitary executive." In broad brushstrokes, unitary executive theory holds that the President must wield all power vested in the executive branch. ${ }^{216}$ What that means in practice, however, varies across different versions of the theory. ${ }^{217}$ Congressional administration of the President's decision-making processes, and in particular the use of process controls to designate and change deciders inside the executive, is in tension with the more aggressive variants of unitary executive theory. Thus far, the courts have broadly accepted congressional structuring of the executive branch, but I discuss these debates here to explain how they would engage with congressional administration of foreign policy. ${ }^{218}$

${ }^{213}$ See Statement on Signing the Foreign Relations Authorization Act, Fiscal Years 1994 and 1995, 1 Pub. Papers 807, 808 (Apr. 30, 1994) (noting that the President's power "includes special authority in the area of foreign affairs," and that the President will "construe" any provisions in the legislation that would interfere with those prerogatives as "precatory").

${ }^{214}$ See Zivotofsky v. Kerry, 135 S. Ct. 2076, 2084-85 (2015); Am. Ins. Ass'n v. Garamendi, 539 U.S. 396, 414-15 (2003). For dissections of the Court's "normalization" of its foreign policy jurisprudence, see Harlan Grant Cohen, Formalism and Distrust: Foreign Affairs Law in the Roberts Court, 83 Geo. Wash. L. Rev. 380 (2015); Ganesh Sitaraman \& Ingrid Wuerth, The Normalization of Foreign Affairs Law, 128 Harv. L. Rev. 1897 (2015).

${ }^{215}$ See supra notes $109-10$.

${ }^{216}$ See, e.g., Steven G. Calabresi \& Saikrishna B. Prakash, The President's Power to Execute the Laws, 104 Yale L.J. 541 (1994).

${ }^{217}$ See, e.g., Mark Tushnet, A Political Perspective on the Theory of the Unitary Executive, 12 U. Pa. J. Const. L. 313, 313 (2010).

${ }^{218}$ See Free Enter. Fund v. Pub. Co. Accounting Oversight Bd., 561 U.S. 477, 508, 513-14 (2010) (upholding the constitutionality of the Public Company Accounting Oversight Board but severing as unconstitutional the rule creating two layers of constraint on the board members' removal); Morrison v. Olson, 487 U.S. 654, 696-97 (1988); Humphrey's Ex'r v. United States, 295 U.S. 602, 627-30 (1935) (upholding the constitutionality of independent agencies); Kagan, supra note 13 , at 2250-51. 
In its most aggressive form, a unitary executive theory might hold that any formal constraints on a President's ability to exercise executive power-including through delegating that power to an official other than the President - would pose an unconstitutional constraint. ${ }^{219}$ Of course, that would mean the dismantling of most delegations of power to the agencies making up the administrative state. The more widely held view of the unitary executive, however, accepts the general structure of administrative delegations to agency officials rather than to the President. ${ }^{220}$ But such delegations are acceptable because, in their view, presidential control of executive power is effectuated through the vesting of final decision-making authority in the President or officials under his or her control by way of removal. In effect, the argument goes, the President must hold unfettered discretion to appoint and remove officials who wield executive power. The courts have to date nevertheless upheld Congress's power to insulate certain agencies and officials from presidential control. ${ }^{221}$ In any event, Congress has virtually never sought to insulate the foreign policy or national security administration through such restrictions on appointment or removal power. ${ }^{222}$

Here is where unitary executive theory could intersect with debates about the proper allocation of foreign affairs and national security power between the President and Congress. Might there be some distinction between the kinds of agencies or powers Congress can insulate from presidential control? Could Congress insulate executive branch actors in their exercise of powers where the President holds some concurrent authority with Congress, such as at least some foreign policy or national security powers? Were Congress to seek to insulate certain actors or decision-making processes from presidential control in areas where the President has traditionally asserted Article II authority, such measures could bring questions of both the viability of unitary executive theory and the allocation of foreign affairs power to a head.

219 Tushnet, supra note 217, at 319. Professor Gary Lawson has argued further that the President may have the power to nullify the acts of subordinates. See Lawson, supra note 190, at $1244-45$.

${ }^{220}$ Tushnet, supra note 217, at 315-18 (describing what he terms the "weak" version of the unitary executive).

${ }^{221}$ See, e.g., Morrison, 487 U.S. at 659-60.

222 See Morrison, 487 U.S. at 675-76; Humphrey's Ex'r, 295 U.S. at 630-32. One potential, though narrow, exception could involve efforts by some in Congress to protect the Mueller investigation into Russian interference in the 2016 presidential campaign. See, e.g., Special Counsel Independence and Integrity Act, S. 2644, 115th Cong. § 599K-8 (2018). 
Congressional attempts to manage the President's foreign affairs and national security decision making therefore could provide the next flashpoint at which each of these constitutional questions arise in the courts. This will likely turn on how aggressively Congress seeks to deploy process controls to establish formal buffers between the President and executive branch decision makers in areas where the President has traditionally asserted independent or even plenary authority to act.

\section{Mollification of Congress}

One risk of deploying process controls is that - by giving members of Congress a sense that they are controlling the decision-making processthis may keep them from engaging further in the substance of policy making. And on some matters, there is no substitute for direct congressional - and through it, public — engagement with the substance of policy making.

This phenomenon may be particularly prevalent when Congress allocates power vertically down the hierarchy within the executive branch to career professionals who are expected to deploy expertise at a remove from partisan interference. In fact, members of Congress might be more reticent to endorse grants of power to the President - in particular to Presidents of the opposing party-were they not assured this power would be partly wielded (and perhaps tempered) by nonpartisan professionals within the government. ${ }^{223}$ And thus congressional delegations of this sort should be understood as made in reliance upon existing bureaucratic constraints. I have previously referred to this phenomenon as congressional "bargain[ing] in the shadow of the bureaucracy." 224

Professor Jack Goldsmith and Susan Hennessey nodded toward such a phenomenon in their discussion of the reauthorization of FISA Section $702 .{ }^{225}$ In response to criticism of Democratic lawmakers who voted to

${ }^{223}$ See, e.g., Lawson, supra note 190, at 1245 ("Judging from the political conflict that is often generated by disputes between Congress and the President, it is at least arguable that Congress would never have granted agencies their current, almost-limitless powers if Congress recognized that such power had to be directly under the control of the President.").

${ }^{224}$ Ingber, Bureaucratic Resistance, supra note 52, at 179-81 (citing Robert H. Mnookin \& Lewis Kornhauser, Bargaining in the Shadow of the Law: The Case of Divorce, 88 Yale L.J. 950, 968-69 (1979)).

225 Jack Goldsmith \& Susan Hennessey, The Merits of Supporting 702 Reauthorization (Despite Worries About Trump and the Rule of Law), Lawfare (Jan. 18, 2018, 9:20 AM), https://www.lawfareblog.com/merits-supporting-702-reauthorization-despite-worries-abouttrump-and-rule-law [https://perma.cc/NV7Q-JNXD]. 
reauthorize broad surveillance powers to the President while Trump held the office, Goldsmith and Hennessey suggest that these members of Congress did so only because of their understanding that the powers would be employed largely by "career public servants" within agencies that "are remarkably immune from inappropriate presidential meddling." 226 But while deference to expertise may be reassuring, particularly in highly technical areas or in times of high political drama, this ability to push hard decisions to apolitical actors may also give Congress a means of abdicating its own responsibility to promote informed and public debate.

Of course, none of this necessarily means that bureaucratic actors can easily thwart the will of political leadership. ${ }^{227}$ A President or other political actor determined to act will often manage to do so if willing to accept the political consequences, including not only the consequences of the policy itself, but also of being seen to thwart her own advisors or the career bureaucracy. And congressional administration of decision making inside the executive branch is not a holistic solution to presidential mismanaging of foreign relations. A President who is willing to face the consequences of doing so can generally force the executive branch to bend to her will. With respect to those officials who hold high-level positions in the executive branch, like heads of departments and White House staffers, the President may appoint whom she chooses, and she may order officials beneath her to take, or not take, certain actions. ${ }^{228}$ As I discuss above, those who decide they cannot follow his orders typically resign. ${ }^{229}$ Or the President may remove recalcitrant officials who refuse her directions. ${ }^{230}$

There are some process answers to the above problems. If political actors interfere with decision making in a way that upends congressional faith in the internal processes they created, members of Congress may

${ }^{226} \mathrm{Id}$.

227 See, e.g., Ingber, Bureaucratic Resistance, supra note 52, at 214.

${ }^{228}$ U.S. Const. art. II, § 2, cl. 2.

${ }^{229}$ See Resignation Letter from James Mattis, Sec'y of Def., to President Donald Trump (Dec. 20, 2018), https://media.defense.gov/2018/Dec/20/2002075156/-1/-1/1/letter-fromsecretary-james-n-mattis.pdf [https://perma.cc/U8PZ-XJBF].

${ }^{230}$ See, e.g., Evan Perez \& Jeremy Diamond, Trump Fires Acting AG After She Declines to Defend Travel Ban, CNN (Jan. 31, 2017, 2:37 PM), https://www.cnn.com/2017/01/30/politics/donald-trump-immigration-order-department-of-justice/index.html [https://perma.cc/H2WY-HSTW] (discussing the firing of acting Attorney General Sally Yates); see also Humphrey's Ex'r v. United States, 295 U.S. 602, 626-32 (1935) (describing executive removal power). 
turn to different process controls, for example, by directly requiring the involvement of very specific actors - such as with the proposed DETER Act. ${ }^{231}$

Ultimately, the final constraints on the President's abuse of congressional controls lie outside the executive branch. They are political - such as outcry at the firing of officials who insist on following congressional requirements against the President's will - and, to a lesser extent, judicial - to the extent the administration refuses to engage a reviewable statutory requirement. Both of these remedies require the other branches to step up and engage more directly. Thus, to the extent congressional administration pacifies Congress's need to act and keeps it from engaging further, this is a real threat to oversight of the executive branch.

\section{Overeager and Unwilling Deciders}

Much deliberation over how to structure government rests on assumptions that the players are power seeking. ${ }^{232}$ And Congress's ability to shift power dynamics inside the executive branch creates avenues for internal actors to, in effect, lobby Congress to give them greater decisionmaking authority. Executive officials working with Congress to push a legislative agenda is itself normal process; much legislation is the result of congressional-executive wrangling, and executive branch officials regularly seek legislation and work with counterparts in Congress to accomplish it. ${ }^{233}$ A request for changes in decision-making authorityversus substantive policy - may be based in genuine consideration of the best allocation of expertise and resources. It may also, however, be deployed by internal actors who simply want greater power to gain a leg up in interagency conflicts through outside assistance from Congress.

But not all designations of deciders are the result of requests for more power, and not all power is desired. Many executive officials may not

${ }^{231}$ Defending Elections from Threats by Establishing Redlines Act of 2019, S. 1060, 116th Cong. § 101 (2019).

${ }^{232}$ See, e.g., William A. Niskanen, Jr., Bureaucracy and Representative Government 38-40 (1971) (arguing that bureaucrats seek to maximize their power, e.g., through their budgets).

${ }^{233}$ See, e.g., 1988 BRAC Report, supra note 132, at 6-9 (discussing efforts by executive branch officials to seek legislative relief from the base closure stalemate); The President's Private Sector Survey on Cost Control: Report on the Office of the Secretary of Defense 103 (1983) (proposing a nonpartisan commission to address base closures). 
always appreciate an allocation of power in their direction. ${ }^{234} \mathrm{~A}$ designation of decision-making authority, even if crafted as one of simple "fact-finding," may put the designee in quite an awkward position vis-àvis her boss, the President, or other officials. ${ }^{235}$ Particularly executive branch actors who view their roles as engaging in fact finding and analysis, rather than policy making, may view a process control that places their approval as the fulcrum for a decision as forcing them to act outside of their ordinary mandate. ${ }^{236}$

That executive branch officials may not always seek or want policymaking authority runs counter to the orthodoxy that government officials seek to aggrandize power; but so too does Congress's slow abdication of power over time to the executive branch, contrary to the Madisonian ideal of the separate branches as checking one another through their clashing hungers for power. ${ }^{237}$ And yet here we are. Government actors do not always find that more responsibility, or more power, is necessarily in their self-interest. ${ }^{238}$ Whether imposing on these officials despite their reticence is in the public interest, however, is another question. In at least some of these cases, it is worth considering that officials given roles that they deem to fall outside of their mandate, expertise, or competence may actually be right about their mandate, expertise, or competence (or at least

${ }^{234}$ See, e.g., James Q. Wilson, Bureaucracy: What Government Agencies Do and Why They Do It 179-95 (1989) (countering the theory that agencies are "imperialistic" with evidence that often they do not seek or even seek to avoid increases in budget or power).

${ }^{235}$ Several Defense Secretaries responsible for certifying the Guantanamo transfers have discussed the awkward position this placed them in: required by law to make a public certification for which they would bear responsibility and yet facing a President who had made Guantanamo closure a signature promise. See, e.g., Department of Defense Authorization for Appropriations for Fiscal Year 2012 and the Future Years Defense Program: Hearing on S. 1253 Before the S. Comm. on Armed Servs. Part 1, 112th Cong. 49 (2011) (statement of Robert Gates, Sec'y of Def.) (testifying that the congressional certification requirements had put him in an "uncomfortable position of having to certify people who get returned"); Bruck, supra note 100 (quoting former Secretary of Defense Chuck Hagel discussing the "immense pressure" he felt from the President, as against the sentiment in DOD that there should be an extremely high bar to release).

${ }^{236}$ Intelligence analysts, in particular, view the role of their offices as providing information and analysis and often seek to avoid a suggestion that they might be crafting policy. This makes the proposal in the DETER Act, which would make a major policy decision-here a sanctions regime - turn on the word of an intelligence agency-here ODNI- unusual. See Defending Elections from Threats by Establishing Redlines Act of 2019, S. 1060, 116th Cong. $\S \S 101,202$ (2019).

237 The Federalist No. 51, at 322 (James Madison) (Clinton Rossiter ed., 1961) ("Ambition must be made to counteract ambition.").

${ }^{238}$ Levinson \& Pildes, supra note 160, at 2315. 
the latter two, as the first will inevitably shift with the new responsibility). Designations of such officials under such circumstances could follow from a breakdown in process or a lack of viable alternatives - such as a widespread mistrust of the other available officials or of the Presidentin which case Congress might be better suited to making the decision itself than delegating it to the executive branch at all.

\section{Surreptitious Interference with Political Will}

Presidents, much more so than members of Congress, campaign on foreign policy promises. And there is an expectation on the part of the public that they will seek to carry out those promises. Congressional administration may at times permit Congress to stymie presidential prerogatives without necessarily doing so openly and entailing the political cost of directly challenging the President's stated policies through substantive legislation. For example, President Obama campaigned on closing the military detention facilities at Guantanamo Bay. ${ }^{239}$ Once he began the process of doing so in office, congressional opposition to the plan swelled. ${ }^{240}$ Yet rather than directly legislate that Guantanamo be kept open or prohibit transfers entirely - and accept the political heat or credit for doing so-Congress chose to influence the course of Guantanamo closure through less transparent means, by altering the transfer decision-making process. By so doing, Congress was able to play a large role in upending the President's closure agenda, for which he might have reasonably argued he had a public mandate to accomplish. ${ }^{241}$ Because he, and not Congress, bore the brunt of that failed campaign promise, members of Congress who opposed the President politically had political incentives to upset his policies generally, regardless of their belief in the ideal policy outcome, and particularly so if they could do so with few political costs. In the case of Guantanamo, at least some of the members of Congress who supported the process controls would surely

239 Barack Obama, The War We Need to Win (Aug. 1, 2007), https://www.realclearpolitics.com/articles/2007/08/the_war_we_need_to_win.html [https://perma.cc/744MUJQ8].

${ }^{240}$ Charlie Savage, Closing Guantánamo Fades as a Priority, N.Y. Times (June 25, 2010), https://www.nytimes.com/2010/06/26/us/politics/26gitmo.html [https://perma.cc/QF88-MA$\mathrm{CZ}]$.

${ }^{241}$ Manners-Weber, supra note 166, at 1424. ("On the date President Obama signed the first NDAA containing a certification requirement ... there were eighty-nine men waiting on the recommended-for-transfer list. For nearly three years, not one would be approved for transfer."). 
have supported more significant substantive measures as well, but it is impossible to know whether there would have been any political costs borne in that alternative universe. And because the costs to supporting process controls are so low, congressional administration could potentially lead to substantive results that neither the President nor members of Congress who vote for the control measures would supportor would want to be seen supporting - if required to do so directly.

\section{Risks to Accountability and Transparency}

Finally, and to my view most significantly, congressional influence through process controls in lieu of direct substantive engagement with policy can at times weaken, rather than augment, accountability and transparency in foreign policy decision making. In fact, the very same political advantages that members of Congress may seek in deploying indirect mechanisms of influence rather than more direct forms of policy making come hand-in-hand with concomitant disadvantages to transparency and accountability. The extent to which a given control weakens or strengthens accountability and transparency of decision making depends on the particular control at issue, how it functions, and the plausible alternatives against which it might be measured.

Arguably, the Constitution allocates to Congress certain powers, such as the power to declare war, or to regulate international commerce, at least in part because the Framers wanted certain types of decisions to be made within the context of public debate, by the branch most closely accountable to the public. ${ }^{242}$ Yet in contrast to the substantive control by Congress of the merits of a particular policy objective, congressional attempts to influence policy by manipulating the inner workings of the executive branch, and specifically by designating as the decision makers its politically insulated bureaucrats, entail significantly less transparency or direct accountability for the substantive positions taken. This is not to say that Congress itself is somehow legislating in secret; its enactment of legislative process controls itself is as transparent as would be substantive legislation. But it is the subsequent process of substantive decision making by actors inside the executive branch that may become more shielded from public view or voters' control. In fact, that lack of political accountability is often the point: whether out of a belief that the decision is better made by technocrats without partisan political influence, or

${ }^{242}$ U.S. Const. art. I, $\S \S 1-3,8$. 
because members of Congress want to shield themselves from political costs, or both, Congress often deploys process controls in lieu of substance specifically because it sets the substantive decision apart from political accountability. ${ }^{243}$

The extent to which a given process control engages more or less accountability, however, depends on the nature of the control itself and on the baseline against which it is judged. Process controls may be deployed specifically to raise a decision from the ranks of unknown bureaucratic actors to a designated high-level official. Such was the case with the Guantanamo certification requirements, in which case Congress's choice of process control took the decision-making authority over transfers from an unnamed panel of bureaucrats who issued determinations as a group and handed it to a not-overjoyed Secretary of Defense for his personal sign off. ${ }^{244}$ In comparison to members of Congress or the President, the unelected Secretary of Defense is less accountable and certainly does not face the voters' wrath directly unless he later decides to run for elected office. But as compared to decision making by a group of faceless bureaucrats, there is more personal accountability in a decision made by a named high-level official such as the Secretary of Defense. The many accounts by former Secretaries of Defense who reported finding these requirements to be a significant, painful burden supports the intuition that the direct designation of a decision maker does create a sense of accountability for one's decisions. ${ }^{245}$ And yet, as I discuss above, as a matter of political accountability, this process control allowed members of Congress to hinder a public promise upon which the elected President had campaigned, with little to no political risk themselves in doing so.

There are two stages at which accountability may be measured: the point of legislating the process control and the point of substantive decision making. As this example demonstrates, at stage one, process

\footnotetext{
${ }^{243}$ See, e.g., supra Subsection II.C.3 (discussing military base closures).

${ }^{244}$ See supra Subsection II.C.1.

245 See, e.g., Manners-Weber, supra note 166, at 1428 ("By localizing accountability in a single person, certification requirements concentrate risk in that person. Personal responsibility brings personal vulnerability. Moreover, these certifications must be memorialized in writing, heightening the vulnerability: should things go wrong, there is a clear record both of the certifier's responsibility and of her poor judgment. This vulnerability changes the certifier's overall decision-making calculus; under the right set of factors, the decisionmaker may become unwilling to make a decision that she would have made otherwise." (footnote omitted)).
} 
controls permit members of Congress to influence substance with less political accountability than they would risk for substantive legislation, though this can be mitigated to some degree by awareness about the effects of these controls.

For the second stage, the specific function the process control implements and the baseline against which it operates are both critical factors in determining the extent to which a given process control aids or weakens accountability for specific officials inside the executive branch.

But weighing congressional administration against more direct substantive congressional engagement is not necessarily a fair comparison. An alternative universe in which Congress legislates substance up to the extent of its formal authorities might be one in which foreign policy is more accountable to public opinion (putting aside for the moment whether that would be a normatively desirable outcome). But considering Congress's historical trajectory at this point, it is not a realistic one. ${ }^{246}$ Therefore, while it is wise to compare the accountability effect of different types of process controls as against one another, it is not generally realistic to compare them to direct substantive congressional engagement.

Counterintuitively, the duly elected President is not necessarily a more accountable "designated decider" than a specific named official in his cabinet. While designating the President as decider might formally appear to place the reins in more publicly accountable hands, the functional reality is that the President-as-designee does not effectuate the same personal accountability features that would any-other-named-official-asdesignee. This is so for several reasons, among them the fact that the President will be held vaguely accountable for all decisions emanating from his term in office, whether within or not within his control, and the sheer enormity may tend to swallow up any given decision. ${ }^{247}$ But more importantly for our purposes, presidential decisions and pronouncements

\footnotetext{
${ }^{246}$ See supra Part I.

247 See "The Buck Stops Here" Desk Sign, Harry S. Truman Presidential Library \& Museum, https://www.trumanlibrary.org/buckstop.htm [https://perma.cc/33LQ-5H8X] (discussing President Truman's oft-stated motto, "the buck stops here," meaning "the President-whoever he is - has to decide. He can't pass the buck to anybody"). But cf. Remarks by President Trump Before Marine One Departure, White House (Jan. 10, 2019), https://www.whitehouse.gov/briefings-statements/remarks-president-trump-marine-onedeparture-30/ [https://perma.cc/3G3S-MXUE] (President Trump stating, "[T]he buck stops with everybody" in response to the question: "Does the buck stop with you over this shutdown?").
} 
are often the result of processes that take place far below his radar, via group decision making by unnamed officials, whom the President and her subordinates will often designate and task secretly. ${ }^{248}$ Thus, neither direct congressional engagement with substance nor direct decisions by the President are, as a realistic matter, necessarily more "accountable" options against which to measure congressional administration. Instead, specific process controls, decision-making processes, and their distinct implications must be weighed against each other and against a realistic assessment of the plausible alternatives.

\section{CONCLUSION}

Congressional administration of executive branch decision making provides a means for Congress to move past the impasses that often hinder direct congressional action in the foreign affairs and national security spaces. The process controls I analyze in this Article permit members of Congress to advance policy preferences, push back against a President whose policies they mistrust, or resolve politically fraught quandaries by placing them in the hands of experts, without many of the policy and political risks that often get in the way of substantive legislation. And yet, despite their salience, the influence of process controls on the foreign policy and national security decision-making process is often absent from debates about the allocation of these powers between the President and Congress.

The use of process controls to designate deciders within the executive branch is particularly effective when it exploits known tensions, which provide opportunities for Congress to influence policies through strategic use of pressure points on the internal decisional process. Congress-and the courts, as I will discuss in a future paper-might deploy this mechanism of oversight even more instrumentally as a means of playing a more significant role in national security and foreign relations without necessarily infringing on the executive's comparative advantages of speed, expertise, and knowledge, or undermining the United States' "one voice" in foreign affairs.

Process controls are not a panacea, and they are not without risk. Indirect influence through legislation of process is not always superior to direct substantive legislation, and the existence of this half measure may

\footnotetext{
${ }^{248}$ Even when the President creates processes publicly through, e.g., executive order, the specific officials are often unnamed. See Exec. Order No. 13,567, 3 C.F.R. § 3 (2011).
} 
at times prevent Congress from taking more direct action. Moreover, process controls entail certain risks - to efficient decision making, to accountability, and to public engagement with foreign affairs and national security decisions. Choosing the proper control requires consideration of context, purpose, and the state of play inside the executive branch.

Nevertheless, process controls offer three critical advantages to direct substantive legislation. First, they provide a means for members of Congress to influence policy without necessarily incurring the political costs that often keep them from engaging. Thus, to the extent congressional involvement is important, process controls may often be the only game in town. Second, process controls may be more effective than direct mandating of policy, as they act through the commandeering of officials inside the executive branch, often before decisions even reach the President, rather than through direct interbranch conflict, which the President may be more inclined to thwart. And finally, process controls provide a means of congressional influence on policy while still benefiting from the executive branch advantages of information, expertise, and dispatch. Ultimately, process controls can be an important tool Congress may and should deploy to push back against the President, giving that branch some concrete means to complement the President's creeping claims to unilateral power in the foreign affairs and national security spheres. 